\title{
Observed and expected changes in wildfire- conducive weather and fire events in peri-urban zones and key nature reserves of the Czech Republic
}

\author{
Mirek Trnka ${ }^{1,2, *}$, Jan Balek ${ }^{1,2}$, Martin Možný ${ }^{1,3}$, Emil Cienciala $^{1,4}$, Petr Čermák ${ }^{5}$, \\ Daniela Semerádová ${ }^{1}$, František Jurečka ${ }^{1,2}$, Petr Hlavinka ${ }^{1,2}$, Petr Štěpánek ${ }^{1,6}$, \\ Aleš Farda' ${ }^{1}$, Petr Skalák ${ }^{1}$, Jana Beranová ${ }^{1,4}$, Filip Chuchma ${ }^{6}$, Pavel Zahradníček ${ }^{1,6}$, \\ Dalibor Janouš ${ }^{1}$, Zdeněk Žalud ${ }^{1,2}$, Martin Dubrovský ${ }^{1,7}$, Pavel Kindlmann ${ }^{1,8}$, \\ Zdeňka Křenová $^{1,8}$, Milan Fischer ${ }^{1,2}$, Jakub Hruška ${ }^{1,9}$, Rudolf Brázdil ${ }^{1,10}$ \\ ${ }^{1}$ Global Change Research Institute of the CAS, Bělidla 986/4a, 60300 Brno, Czech Republic \\ ${ }^{2}$ Mendel University in Brno, Institute of Agrosystems and Bioclimatology, Zemědělská 1, 61300 Brno, Czech Republic \\ ${ }^{3}$ Czech Hydrometeorological Institute, Na Šabatce 17, 14306 Praha, Czech Republic \\ ${ }^{4}$ Institute of Forest Ecosystem Research (IFER), Čs. armády 655, 25401 Jílové, Czech Republic \\ ${ }^{5}$ Mendel University in Brno, Dept of Forest Protection and Wildlife Management, Zemědělská 3, 61300 Brno, Czech Republic \\ ${ }^{6}$ Czech Hydrometeorological Institute, Kroftova 43, 61667 Brno, Czech Republic \\ ${ }^{7}$ Institute of Atmospheric Physics of the CAS, Boční II 1401, 14100 Praha, Czech Republic \\ ${ }^{8}$ Institute for Environmental Studies, Faculty of Sciences, Charles University, Benátská 2, 12801 Praha, Czech Republic \\ ${ }^{9}$ Czech Geological Survey, Klárov 3, 11821 Praha, Czech Republic \\ ${ }^{10}$ Institute of Geography, Masaryk University, Kotlářská 2, 61137 Brno, Czech Republic
}

\begin{abstract}
Recent drought and a surge in days with weather conditions conducive to wildfire occurrence during 2015-2019 reminded the Czech Republic that it is not immune to this type of natural hazard. Although Central Europe has not been at the center of such events, observed climate data and climate projections suggest a tendency toward more years with wet and mild winters and dry and hot summers. To fill the existing knowledge gap, we used an ensemble of 9 fuel aridity metrics, including 3 dedicated fire weather indices, and evaluated their level of agreement with actual fire occurrence and their temporal trends. The analysis included periurban zones of the 36 largest cities and towns in the Czech Republic (home of 3.8 million inhabitants) and the 29 largest protected areas (covering $13.7 \%$ of the territory). Fire weather climatology, based on both the Fire Weather Index and the Forest Fire Danger Index, agreed well with the long-term frequency of fires both in peri-urban zones and within protected areas. Future projections based on regional and global model ensembles indicated a significant increase in fuel aridity and an increase in the area affected by fire-conducive conditions both around urban areas and within protected regions. In particular, the area affected by days with very high risk fire weather conditions is likely to increase significantly relative to the past $60 \mathrm{yr}$. However, the magnitude of the projected change depends to a large degree on the selected fire weather metric and whether RCM- or GCM-based scenarios are used.
\end{abstract}

KEY WORDS: Wildfire - Fire weather index - Climate change - Regional climate model . Global circulation model $\cdot$ Nature reserve $\cdot$ Peri-urban zone $\cdot$ Czech Republic

\section{INTRODUCTION}

Fire is considered an integral component of global ecosystems (e.g. Abatzoglou et al. 2018). Its impor-

\footnotetext{
*Corresponding author: mirek_trnka@yahoo.com
}

tance for the Earth's system through its influence on the terrestrial carbon cycle has been documented (e.g. Bond-Lamberty et al. 2007, Kurz et al. 2008, Bowman et al. 2009, Pellegrini et al. 2018). From the 
human perspective, we can understand fire as both a natural disturbance that is prevalent across most land surfaces and an anthropogenic disturbance process with regular ignitions from humans, particularly in pastoral and agricultural areas where fire is often used as a tool (Cochrane 2003). However, if we focus on densely populated areas or smaller wildlife protected areas, fire can also be viewed as a hazard to some ecosystem services, posing threats to the settlements themselves and to human health (Johnston et al. 2011, Reid et al. 2016). This threat has been reinforced by recent extreme fire events associated with extensive loss of human life (Cruz et al. 2012, Boer et al. 2017, Bowman et al. 2017). These losses have increased efforts related to monitoring, modeling and predicting fire across time and space (Abatzoglou \& Williams 2016). The fire season of 20192020 in Australia has shown that even in countries considered to be well adapted to the periodic occurrence of wildfires, the intensification of wildfires attributed to climate change increases the vulnerability of both peri-urban and wildlife protected areas. At the same time, the occurrence of the 2018 fire wave in Sweden prompted wildfire research in countries that were not previously considered to be at risk, such as the Czech Republic (e.g. Adámek et al. 2018, Jurečka et al. 2019).

Several biophysical and anthropogenic factors have been described as key contributors to the fire activity. Obviously, any wildfire requires sufficient fuel, i.e. a biomass source, flammability and an ignition source (e.g. Bradstock et al. 2009, Bradstock 2010). These factors often provide constraints on fire activity, both spatially (Krawchuk et al. 2009) and temporally (Littell et al. 2016), with the influence of individual factors varying across vegetation productivity gradients (Pausas \& Ribeiro 2013). The influences of anthropogenic activities, including landuse modification, human ignitions and fire suppression, further complicate the influence of purely biophysical drivers of fire activity (Andela et al. 2017, Balch et al. 2017, Adámek et al. 2018, Možný et al. 2020). Anthropogenic activity can both decrease and increase biophysical drivers and enablers of fire (Taylor et al. 2016). The dynamic nature of weather and climate relative to other factors implicates atmospheric processes as the predominant macroscale driver of temporal variability in fire activity (e.g. Aldersley et al. 2011). While Central Europe and the Czech Republic do not have large burn areas - only approximately 100 to 650 ha of forest area are annually burned in the Czech Republic (San-Miguel-Ayanz et al. 2018)-recent studies have shown that (1) climate variability explains a majority of the interannual variability in wildfire numbers (Jurečka et al. 2019, Možný et al. 2020), (2) trends in key climate parameters explain the overall increase in wildfire numbers (Trnka et al. 2020a,b), and (3) local factors also play a significant role (Adámek et al. 2015, 2018, Možný et al. 2020).

Increased fire activity across the Czech Republic landscape has coincided with climatic conditions that are more conducive to wildfire (Trnka et al. 2020a). The strong interannual correlation between forest fire activity and fire season fuel aridity as well as observed increases in the vapor pressure deficit (Trnka et al. 2015), fire danger indices (Jurečka et al. 2019) and climatic water deficit (Trnka et al. 2020b) over the past several decades presents a compelling argument that climate change has contributed to the recent increases in fire activity. Additionally, recent analysis of wildfire number development over time has shown a marked increase in wildfire frequency in areas that have seen an increase in urbanisation (Možný et al. 2020).

As a significant shift in weather conducive to wildfire occurred between 1956 and 2015 and because these shifts coincided with the increase in the number of wildfires reported by Možný et al. (2020), it is essential to research changes in risk posed by wildfires, particularly with a focus on peri-urban zones and nature reserves. The former is important because of the sheer proximity and population exposure levels, and the latter is important because of the biodiversity, water resources and recreational roles of these areas.

Urban areas and settlements in the peri-urban zones in the Czech Republic provide living space for almost half of the country's population. The occurrence of wildfires in the peri-urban zones would be especially damaging around the 3 largest cities (Prague, Brno and Ostrava), which together have almost 2 million inhabitants or one-fifth of the country's population and an even higher proportion of the country's economic output. Urban and industrial areas (e.g. Ostrava) suffer from worse than optimum air quality (e.g. Jiřík et al. 2016, Hůnová \& Bäumelt 2018) despite efforts that have been ongoing since the early 1990s. An increase in wildfire activity would worsen the air quality, as has been seen in other parts of the world, such as Russia (Konovalov et al. 2011), California (Liu et al. 2017) and Australia (Johnston et al. 2011).

Most of the relatively undisturbed or valuable ecosystems in the Czech Republic are found within 


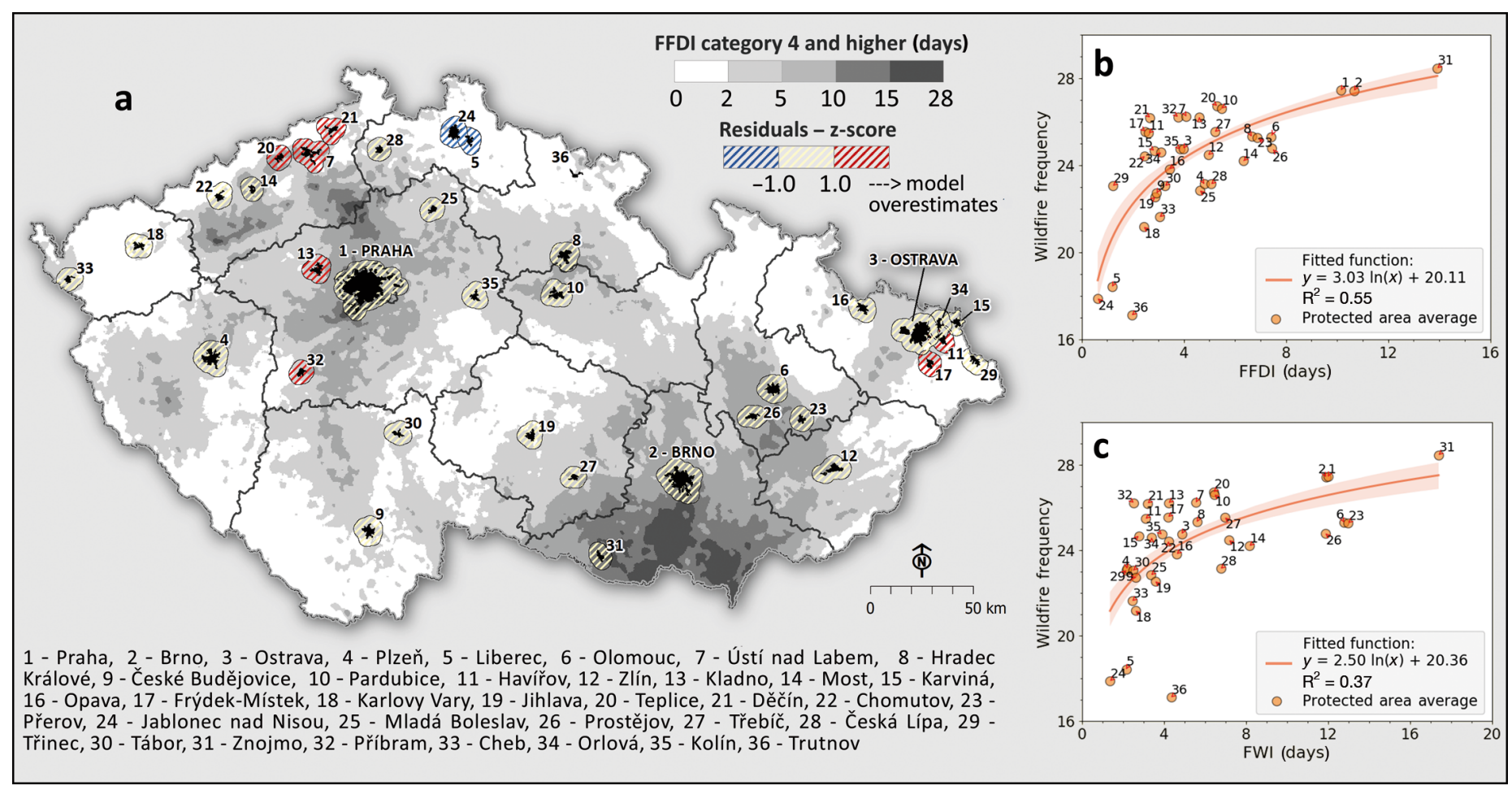

Fig. 1. (a) Delimitation of the peri-urban zones used in the study (Table S1 in the Supplement at www.int-res.com/articles/suppl/c082p033_ supp.pdf). (b,c) Relationships between the mean number of days according to the FFDI (b) and the FWI (c) values with high risk of fire (above FD3) during the 1971-2015 period and the number of observed wildfires in the peri-urban zones during the same period. Shading shows an interval of $\pm 1 \mathrm{SD}$. Color of the cross-hatching indicates areas where the observed number of wildfires was higher (red) or lower (blue) than the values estimated by the fitted function (Fig. 2b). FFDI: Forest Fire Danger Index; FWI: Fire Weather Index; FD: fire danger

25 protected landscape areas (PLAs) and 4 national parks (NPs). We use the term nature reserves when we describe all 29 protected areas that have been analyzed. Any shift in fire weather needs to be considered in their management plans and needs to be analyzed because the consequences would be widespread and potentially affect the core reason for the existence of protected areas. Nature reserves protect the remnants of natural or seminatural ecosystems (Pyšek et al. 2002), protect landscape characteristics and provide shelter for rich communities of organisms and, in many cases, unique ecosystems; these areas are also key areas that support water retention and drinking water accumulation (Harmáčková \& Vačkář 2015) and provide recreational space for millions of visitors (Siikamäki et al. 2015).

Considering the change in climate conditions and the key importance of peri-urban areas and nature reserves for the quality of life of the Czech population, we aimed to (1) examine the link between fuel aridity and the occurrence of wildfires in these land use zones over past decades; (2) ana- lyze trends in fuel aridity conditions during past decades over both zones, including the connection to the observed fire frequency; (3) estimate potential changes in fuel aridity parameters in future decades; and (4) estimate the potential impact on the number of wildfires if fire prevention policies are not changed.

\section{DATA AND METHODS}

\subsection{Peri-urban zones}

The peri-urban zones we studied included the 36 largest urban areas (Table S1 in the Supplement at www.int-res.com/articles/suppl/c082p033_supp.pdf) with at least 30000 inhabitants each (according to the 2010 census). These areas were defined as the geographical fringe surrounding the core built-up areas. Those included in the study provide home for over $37 \%$ of the total Czech Republic population, i.e. 3.8 million inhabitants. Their geographical location is shown in Fig. 1. The fringe area considered in this 


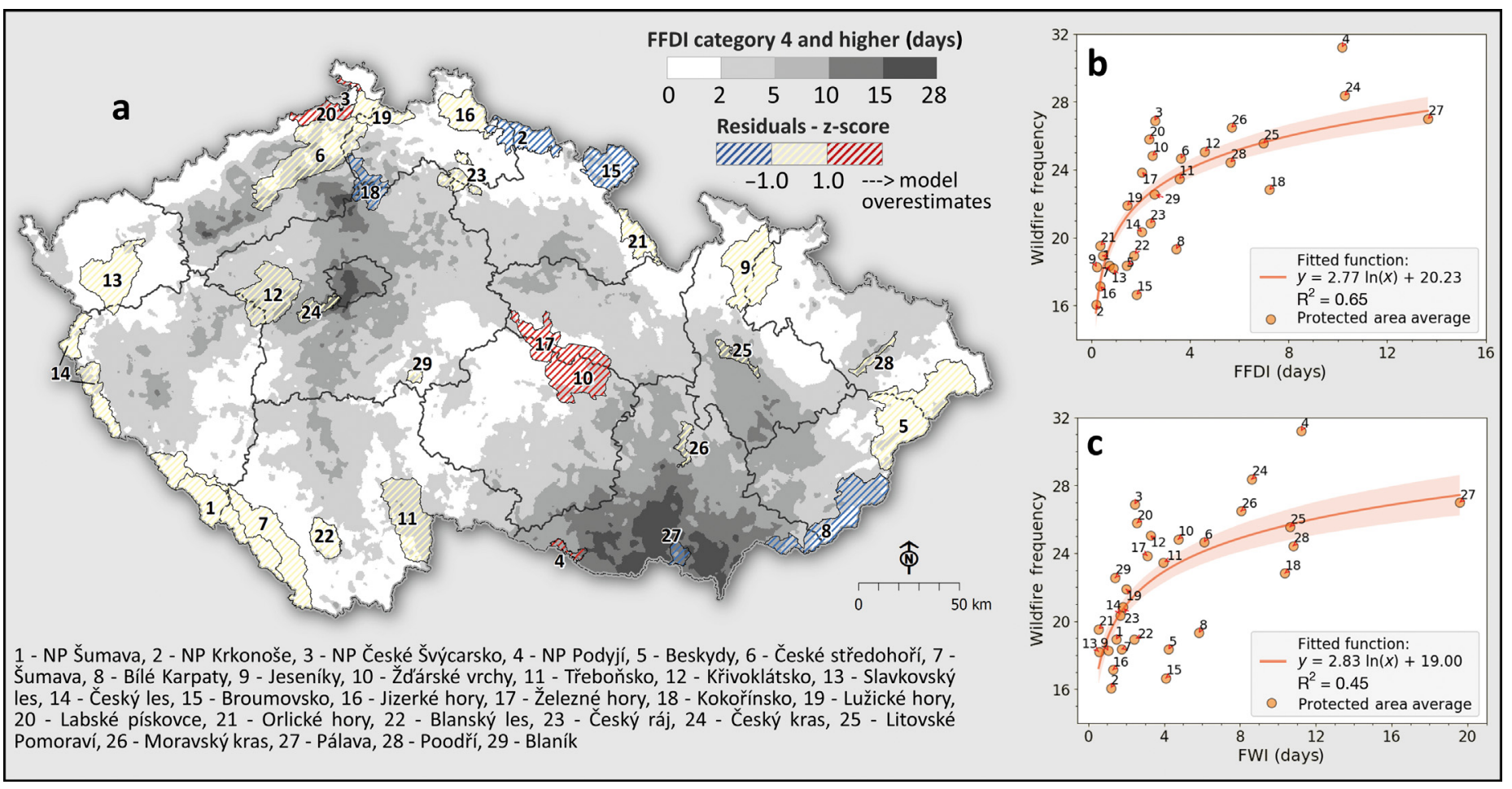

Fig. 2. Same as Fig. 1 but for nature reserves including national parks (1-4) and protected landscape areas (5-29) used in the study (Table S2)

study was set as a constant distance of $4 \mathrm{~km}$ from the city core, and this boundary was determined based on digital vector boundaries for built-up areas. This boundary dataset is part of the Data200 database, a digital geographic model of the territory of the Czech Republic, which corresponds in accuracy and degree of generalization to a map scale of 1:200000, provided by the Czech Office for Surveying, Mapping and Cadastre. The fringe was created using an ArcGIS geoprocessing tool that creates buffer polygons around input features to a specified distance. Based on this definition, the study area of peri-urban zones covers $5300 \mathrm{~km}^{2}$ (Table S1), which represents nearly $7 \%$ of the national territory. The change in population over the periods 1956-1985 and 19862015 is shown in Table S1.

\subsection{Nature reserves}

Protected areas are established to preserve unique and highly valued landscapes and the natural environment and to promote natural restoration. There are 6 categories of protected areas in the Czech Republic, and they are grouped by size. As part of this analysis, we worked with large areas - NPs and
PLAs (Fig. 2, Table S2). NPs constitute territories with unique characteristics at the national or international level and are also important for their cultural ecosystem services, as supported by the number of visitors (Table S2). Most of their territory consists of ecosystems in their natural state or those that are little influenced by humans; additionally, their fauna, flora and abiotic nature have exceptional scientific and educational significance. PLAs usually have similarly large acreages, and they have been created to protect characteristic relief, geomorphological phenomena and/or natural forest and meadow ecosystems as well as to preserve historical settlements. In total, the 4 NPs occupy approximately $1.5 \%$ of the Czech Republic territory, and the 25 PLAs occupy approximately $13.7 \%$ of the Czech Republic territory. Both types of protected areas are based on national Czech legislation. Moreover, a coordinated network of sites with common European Union legislation exists across Europe (Natura 2000), while the selection of species and habitat types is designated by the individual countries. The Czech Natura 2000 network now consists of 1153 sites. The protected areas selected in those studies included 262 sites of the Natura 2000 network, covering almost $77 \%$ of their territory. 


\subsection{Fire risk indices and meteorological data}

We selected 9 metrics as proxies for fuel aridity, some of which have been used in similar studies in the recent past and are known to be linked, for instance, to the area burned (e.g. Williams et al. 2015, Abatzoglou \& Williams 2016). These metrics included (1) reference evapotranspiration (ETr) based on the SoilClim model (Hlavinka et al. 2011), (2) water vapor pressure deficit (VPD), (3) Fire Weather Index (FWI) (Stocks et al. 1989), (4) McArthur Forest Fire Danger Index (FFDI) (McArthur 1967), (5) Finnish Fire Index (FFI) (Heikinhemo et al. 1998), (6) Palmer Drought Severity Index (PDSI) calculated with modifications described in Büntgen et al. (2011), (7) Standardized Precipitation Evaporation Index (SPEI) aggregated over 6 mo (SPEI-6) (Vicente-Serrano et al. 2010), (8) relative soil saturation in the topsoil layer (AWR1), and (9) seasonal deficit of available moisture in the top layer (AWD1). Metrics 8 and 9 came from SoilClim-based drought indicators (Trnka et al. 2015, 2020b). The methods used to calculate all metrics followed the methodology of Trnka et al. (2020b).

Daily meteorological data from 268 climatological and 787 rain gauge stations of the Czech Hydrometeorological Institute were used to calculate the fuel aridity metrics. These data combine temporal attributes and multiple variables from the national drought monitoring system (Trnka et al. 2020b), covering the whole country with daily weather inputs interpolated to $500 \mathrm{~m}$ grids. The daily data were used to calculate the ETr, VPD, FWI, FFDI, FFI, AWR1 and AWD1. Monthly climatic data were applied to calculate the PDSI and SPEI. The approach by Allen et al. (1998) was used to calculate ETr with the Penman-Monteith method. The PDSI was calculated using the monthly ETr, precipitation and soil water holding capacity derived from the database available for the SoilClim model (Trnka et al. 2015). The data had a resolution of $500 \times 500 \mathrm{~m}$. The monthly mean VPD was estimated as the difference between the saturated and actual vapor pressure using the same approach as that in Abatzoglou \& Williams (2016). The saturated vapor pressure is a function of temperature, and the actual vapor pressure is a function of specific humidity and pressure. Daily meteorological fields were used to calculate the FWI, FFDI, FFI, AWR1 and AWD1.
The performances of dedicated fire weather metrics, i.e. FWI, FFDI and FFI, were similar to those of the other 4 metrics, i.e. AWR1, AWD1, VPD and ETr, which were shown by Trnka et al. $(2020 a, c)$ to explain a large portion of fire occurrence on annual, monthly, weekly and daily time steps. The fire weather estimated by these 7 metrics explained between 50.0 and $71.0 \%$ of the variability in the number of actual wildfire incidents on a seasonal scale and 37.6-60.1\% on a daily scale (M. Trnka et al. unpubl.). Based on studies by Jurečka et al. (2019) and Trnka et al. $(2020 \mathrm{a}, \mathrm{c})$, we opted to use the FWI and FFDI combined with the FFI as representative fire weather proxies for the current climate conditions. For characterizing the expected climate, the use of 3 dedicated fire weather indices is preferred, as by design, their values can be directly converted into fire danger levels (Table 1). We used Table 1 to further classify the fire weather conditions on a given day. Detailed formulation and scale selection were based on the paper by Jurečka et al. (2019) and Trnka et al. (2020c).

For the FWI, the scale developed by Van Wagner (1987) was used because it is based on climate conditions similar to those in the Czech Republic. The FWI is an output of the Canadian Forest Fire Danger Rating System (Stocks et al. 1989), which was developed in 1970, with revised versions issued in 1976, 1984 and 1987 (Dowdy et al. 2009). The FWI integrates several components to provide a numerical rating of frontal fire intensity that accounts for fuel dryness and potential fire spread. The FWI system is an important component of the Canadian Forest Fire Danger Rating System but has been adopted by or adapted to a number of other countries with climates different from that of Canada, such as New Zealand, Indonesia and Malaysia (Dudfield 2004, de Groot et

Table 1. Scales of fire danger rating for Fire Weather Index (FWI), McArthur Forest Fire Danger Index (FFDI) and Finnish Fire Index (FFI). Bold categories were considered in the analysis of fire weather days. Number of days or area affected by fire weather rating equal or higher to High (3+) and Very high (4+) fire risk were used throughout the study, e.g. FWI3+ or FWI4+

\begin{tabular}{|c|c|c|c|c|}
\hline \multirow{2}{*}{ Fire danger } & \multicolumn{3}{|c|}{ Index and source } & \multirow{2}{*}{$\begin{array}{c}\text { Fire danger } \\
\text { scale }\end{array}$} \\
\hline & $\begin{array}{c}\text { FWI } \\
\text { Van Wagner } \\
(1987)\end{array}$ & $\begin{array}{l}\text { FFDI } \\
\text { Dowdy et } \\
\text { al. (2009) }\end{array}$ & $\begin{array}{c}\text { FFI } \\
\text { Vajda et } \\
\text { al. (2014) }\end{array}$ & \\
\hline None to very low & $0-1.9$ & $0-4.99$ & $1.0-1.9$ & FD0 \\
\hline Low & $2-4.9$ & & $2.0-2.9$ & FD1 \\
\hline Moderate & $5-8.9$ & $5-11.9$ & $3.0-3.9$ & FD2 \\
\hline High & $9-16.9$ & $12-23.9$ & $4.0-4.9$ & FD3 \\
\hline Very high & $17-29.9$ & $24-49.9$ & $5.0-5.9$ & FD4 \\
\hline Extreme & $>30$ & $>50$ & 6.0 & FD5 \\
\hline
\end{tabular}


al. 2006, Taylor \& Alexander 2006), and Europe (Rodriguez-Aseretto et al. 2013), where it was also implemented into the European Forest Fire Information System (San-Miguel-Ayanz et al. 2012).

The FFDI is based on an empirical approach for assessing fire danger in Australia (McArthur 1967, Griffiths 1998). This index has been widely used to forecast the influence of weather on fire behavior, and the Australian Bureau of Meteorology routinely issues FFDI forecasts for use by fire authorities; the FFDI is a key tool for assessing fire danger in Australia (Dowdy et al. 2009). The formulation of the FFDI (e.g. Noble et al. 1980) is based on temperature, wind speed, relative humidity and drought factor, which represents fuel availability (Dowdy et al. 2009). The scale used for the FFDI follows the paper by Dowdy et al. (2010).

The FFI was developed for forecasting fire danger in Finland. The Finnish Meteorological Institute operationally monitors conditions favorable for forest fire and for managing aerial forest fire monitoring schemes. The FFI value essentially represents the estimated moisture content of a surface layer, which is the main difference between it and the FFDI, where wind speeds/gusts (which represent indicators of fire spread risk) are also important in determining the actual level of fire danger.

Therefore, the total set of metrics used in this analysis consists of 9 fuel aridity indicators. These metrics represent the entire scope of methods, starting from dedicated fire weather indices (FWI, FFDI and FFI), to complex metrics of surface soil layer dryness (AWR1 and AWD1) and drought indices (PDSI and SPEI), to parameters describing the evaporative demand of the atmosphere (VPD and ETr). The annual variations in all of these fuel aridity metrics are presented as standardized anomalies (z-scores) to accommodate differences across geography and metrics. To compute these anomalies, we used the mean and SD $(\sigma)$ from the baseline period of 1956-2015.

Daily records of the number of wildfires, which were defined as unintended fires of vegetation (regardless of vegetation type) outside of urban areas, were used. The data were obtained from the Fire Rescue Service of the Czech Republic for the 19712015 period. The regression analysis between the number of wildfires across peri-urban (Fig. 1) and nature reserve (Fig. 2) areas and the number of highrisk fire weather days was based on the FWI and FFDI. The statistical significance of all trends and correlations reported in this study were assessed using both Spearman's rank and Kendall's $\tau$ statistics in the case of linear trends based on Unistat (R) Statistical Package v.6.5.11 (release 2016). Figs. 1 \& 2 also feature $\mathrm{R}^{2}$, which was used to assess the goodness of the fit. Trends were considered significant if both tests indicated a significant trend at the 0.05 significance level.

\subsection{Future climate scenarios}

To analyze future climate conditions, the regional climate model (RCM) simulations that were carried out within the European part of the global Coordinated Regional Climate Downscaling Experiment (EURO-CORDEX, www.euro-cordex.net) were used as the first choice. The EURO-CORDEX experiment design is based on the utilization of state-of-the-art RCMs forced by global circulation models (GCMs) from the Coupled Model Intercomparison Project (CMIP5) ensemble. EURO-CORDEX RCM simulations deliver new insight into European climate development at 2 spatial scales for 3 greenhouse gas emission scenarios expressed by the representative concentration pathways (RCPs) (van Vuuren et al. 2011). The following 5 GCM-RCM pairs, which were performed at a $0.11^{\circ}$ spatial resolution and considered RCP4.5 (Clarke et al. 2007), were selected from all available EURO-CORDEX simulations: CNRM-CM5/ALADIN53， EC-EARTH/RACMO22E， EC-EARTH/RCA4, MOHC-HADGEM2-ES/RCA4 and MPI-ESM-LR/CCLM4.8.17. This choice was influenced by the availability of the EURO-CORDEX data within the time of preparation of this study and by the effort necessary to capture a variety of the different RCMs and their driving GCMs.

All RCM simulations were corrected for bias by applying the distribution adjusting by percentiles (DAP) method of Štěpánek et al. (2016), which belongs to the family of quantile mapping bias correction methods. For bias correction, we used 212 meteorological stations with daily observations of precipitation and 119 stations with observations of air temperature, humidity and wind speed over the territory of the Czech Republic within the 1981-2010 period. As a part of the DAP method, the RCM data from several nearest grid points were first recalculated into station locations, and then the bias correction itself was performed on the daily data within the 1981-2005 period.

Alternatively, we used a set of 5 GCMs and the delta approach method as used by Trnka et al. (2016) to obtain daily data for each $500 \mathrm{~m}$ grid for the periods 2021-2051 and 2051-2080. GCMs were used as representations of mean values (IPSL model of the Institute of Pierre Simone Laplace, France) and for the best capture of the variability of expected changes in 
precipitation and temperature (BNU, Beijing Normal University, China; MRI, Meteorological Research Institute, Japan; CNMR, National Center for Meteorological Research, France; and HadGEM, Hadley Center Global Environment Model, UK). These models were selected from 40 climate models available in the CMIP5 database (Taylor et al. 2012). We followed the methodology described by Dubrovsky et al. (2015) and used the RCP4.5 greenhouse gas concentration trajectory and a climatic sensitivity of $3.0^{\circ} \mathrm{C}$.

\section{RESULTS}

\subsection{Spatiotemporal variability of fire risk in peri-urban zones}

Fig. 1 shows that peri-urban zones could be classified into 3 groups based on fire weather climatology and the recorded number of wildfires (albeit including mostly very small incidents). The first group with a lower than mean number of recorded wildfires and a comparatively low number of days with suitable fire weather was located in the northern part of the country, including Liberec, Jablonec and Trutnov. The second group represented the majority of the peri-urban zones for which the importance of fire weather as a fire incidence predictor varied greatly. Finally, the third group showed a markedly higher number of fire weather days (as much as 5 times larger than group 1) and a much higher long-term wildfire frequency. This group is particularly interesting because it includes the 2 largest urban areas (Prague and Brno) and Znojmo, a town with 33000 inhabitants that is located in the zone with by far the highest occurrence of fire weather and above mean incidence of wildfires.

When we analyzed the temporal dynamics of the 9 fuel aridity metrics monthly values for April-June averaged across all peri-urban zones of the Czech Republic, we found a significant increase in the 1956-2015 period, with a linear trend of $0.8 \sigma$ in the all-metric mean (Fig. 3a). However, in this period, all fuel aridity metrics showed a marked and significant shift toward fire-conducive conditions. The all-metric mean for July-September was $0.6 \sigma$, although it was not statistically significant. The long-term fuel aridity metrics SPEI-6 and PDSI showed significant trends at both time periods together with the FWI, ETr and VPD in both parts of the summer half-year (Fig. 3e,f). The other 2 dedicated fire indices, the FFDI and FFI, exhibited significant increases in April-June, while the increases in July-September were not found to be significant; however, as shown in Fig. 3b,d,f, they changed toward more fire-conducive conditions. If we consider the peri-urban zones affected by high fuel aridity $(>1 \sigma)$, we also see a marked increase here, which was particularly notable since 1990 (Fig. 3c,d). The area of peri-urban zones with high aridity has been increasing steadily at a rate of $4 \%$ per decade during April-June (Fig. 3e) and 2\% per decade during July-September (Fig. 3f). Significant positive trends in the area with high fuel aridity were observed during April-June for all metrics (Fig. 3e,f) without exception. For July-September, 5 of 9 metrics showed significant trends, with the other 2 metrics (FFI and FFDI) being close to the 0.05 significance level. The changes, however, have not been occurring with the same intensity in all peri-urban zones of the Czech territory.

Fig. 4 shows the analysis of fuel aridity metrics for the peri-urban zones of the 3 largest cities of the country (Prague, Brno and Ostrava), where all of the above-described trends not only held but were also more intense. In particular, the increase in area with high fuel aridity indicates a significant increase of more than $5 \%$ per decade for April-June and $3 \%$ per decade for July-September. Over 60 yr, we analyzed the area in the peri-urban zones of the 3 largest cities, which increased by more than $30 \%$. In some peak years, almost the entire area experienced high fuel aridity conditions (Fig. 4c,d).

As the next step, we analyzed how exposure of the urbanized population to fire conditions in their immediate vicinity has changed over the past $60 \mathrm{yr}$ (Fig. 5). With the increasing area affected by highrisk fire weather conditions, the number of days when such situations occurred also increased (Fig. 5a). The reported trend of increasing fuel aridity was confirmed by the absolute dominance of years from the latter part of the record, i.e. the top 6 events all occurred during the 1986-2015 period. The fire weather trends were more pronounced near large agglomerations (Fig. 4). In addition, the overall share of the population in urban centers showed an increasing trend (Table S1) between 1956-1985 and 1986-2015. As a consequence, exposure of the population in the peri-urban zone of the town or city to high-risk and very high risk fire weather was significantly greater after 1986. The year 2003 stood out in the record (Fig. 5b,c) as a year in which both the largest area and number of inhabitants were potentially affected by the high fire danger weather conditions. This year was closely followed by 1992 and 2015. The 2003 record year has since been passed by the 2018 drought (not shown). 


\section{April - June}
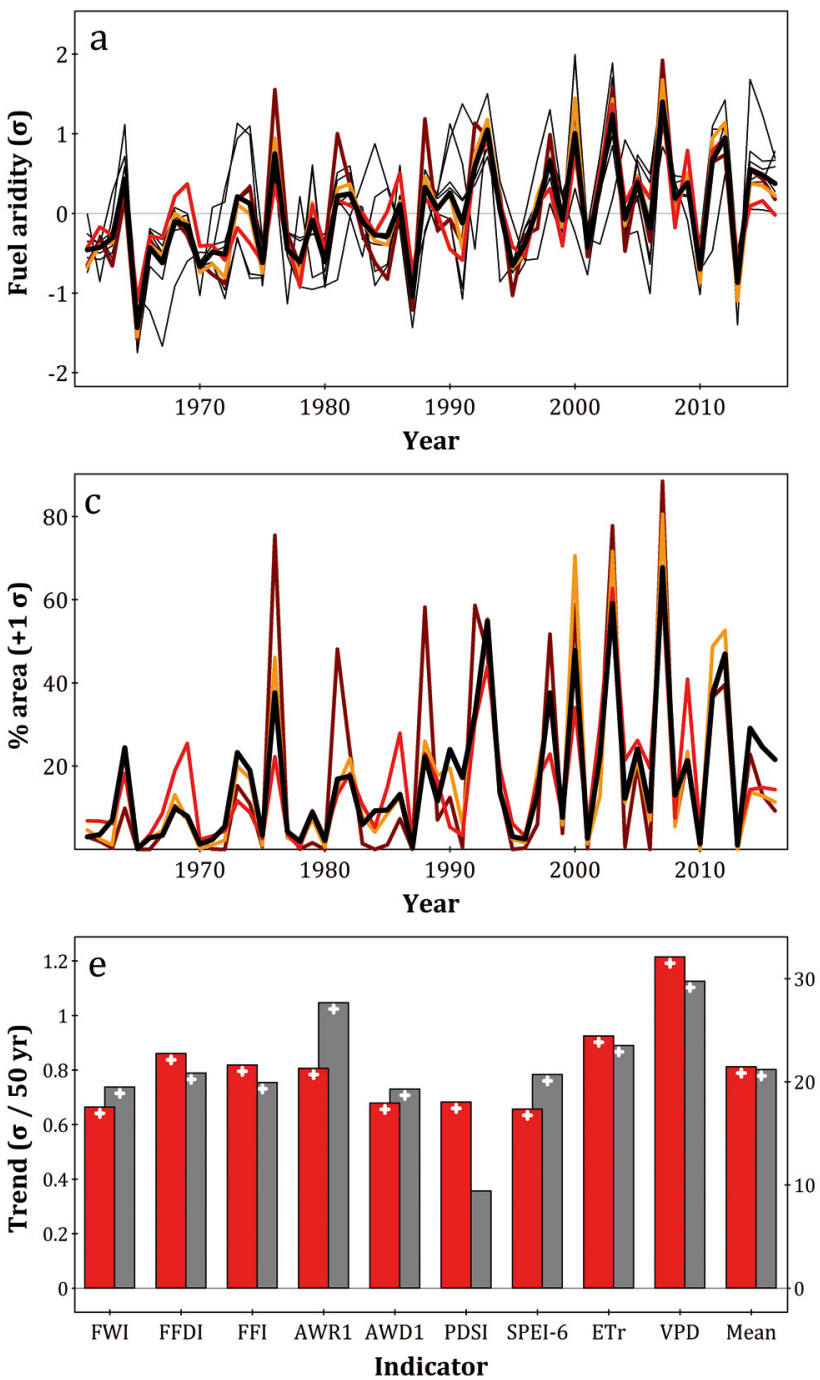

July - September
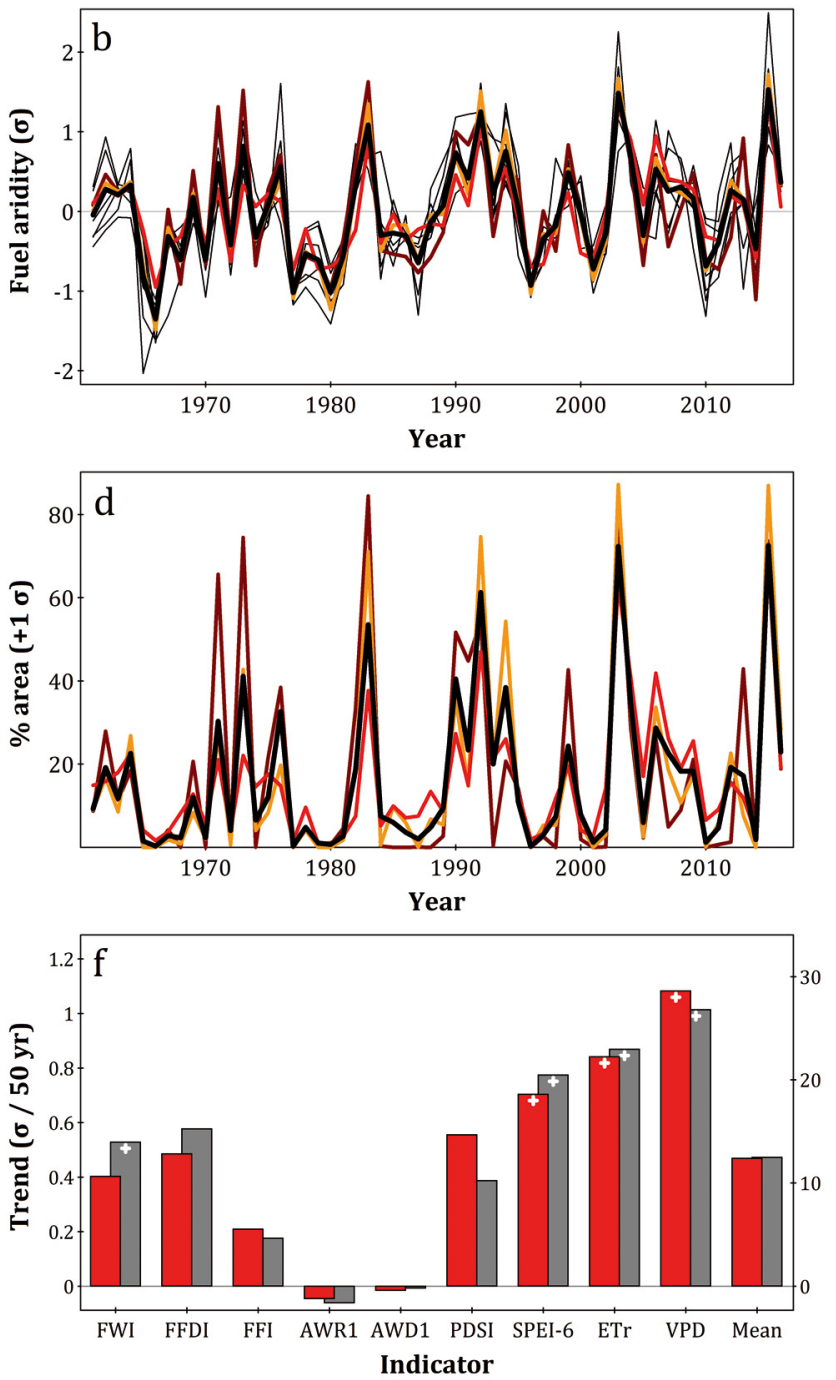

Fig. 3. Fluctuations and trends in the fuel aridity metrics for April-June (left) and July-September (right) across all peri-urban zones of the Czech Republic (Fig. 1a) for the 1956-2015 period. Fluctuations in (a,b) standardized annual fuel aridity metrics and $(\mathrm{c}, \mathrm{d})$ agricultural and forested areas with standardized fuel aridity values exceeding $1 \sigma$. Bold black lines indicate means across fuel aridity metrics. Red lines show values based on the FWI, while orange lines show the FFDI and purple lines show the FFI fire weather indices. Thin black lines in $(a, b)$ show the remaining fuel aridity indicators. (e,f) Linear trends in the standardized fuel aridity metrics (red) and in the area with fuel aridity above 1 SD $(\sigma)$ (gray) during 1956-2015. + indicates a positive trend at the 0.05 significance level. FWI: Fire Weather Index; FFDI: Forest Fire Danger Index; FFI: Finnish Fire Index; AWR1: relative soil saturation in the topsoil layer; AWD1: seasonal deficit of available moisture in the top layer; PDSI: Palmer Drought Severity Index; SPEI-6: Standardized Precipitation Evaporation Index aggregated over 6 mo; ETr: reference evapotranspiration; VPD: vapor pressure deficit

\subsection{Spatiotemporal variability of fire risk in nature reserves}

Fig. 2 indicates that 29 of the nature reserves we analyzed covered the whole range of fire weather conditions, similar to the peri-urban zones. Some reserves with the highest level of protection (e.g. NPs Šumava and Krkonoše) were found in areas with rare occurrences of high-risk fire weather condi- tions, while the other 2 (and much smaller) NPs (České Švýcarsko and especially Podyjí) were located in areas with much higher occurrences of this type of weather condition. Similar to peri-urban zones, nature reserves could also be classified into 3 groups based on fire weather climatology and the recorded number of wildfires. The first group, which includes the 2 largest NPs, Šumava and Krkonoše, showed a lower than mean number of 


\section{April - June}
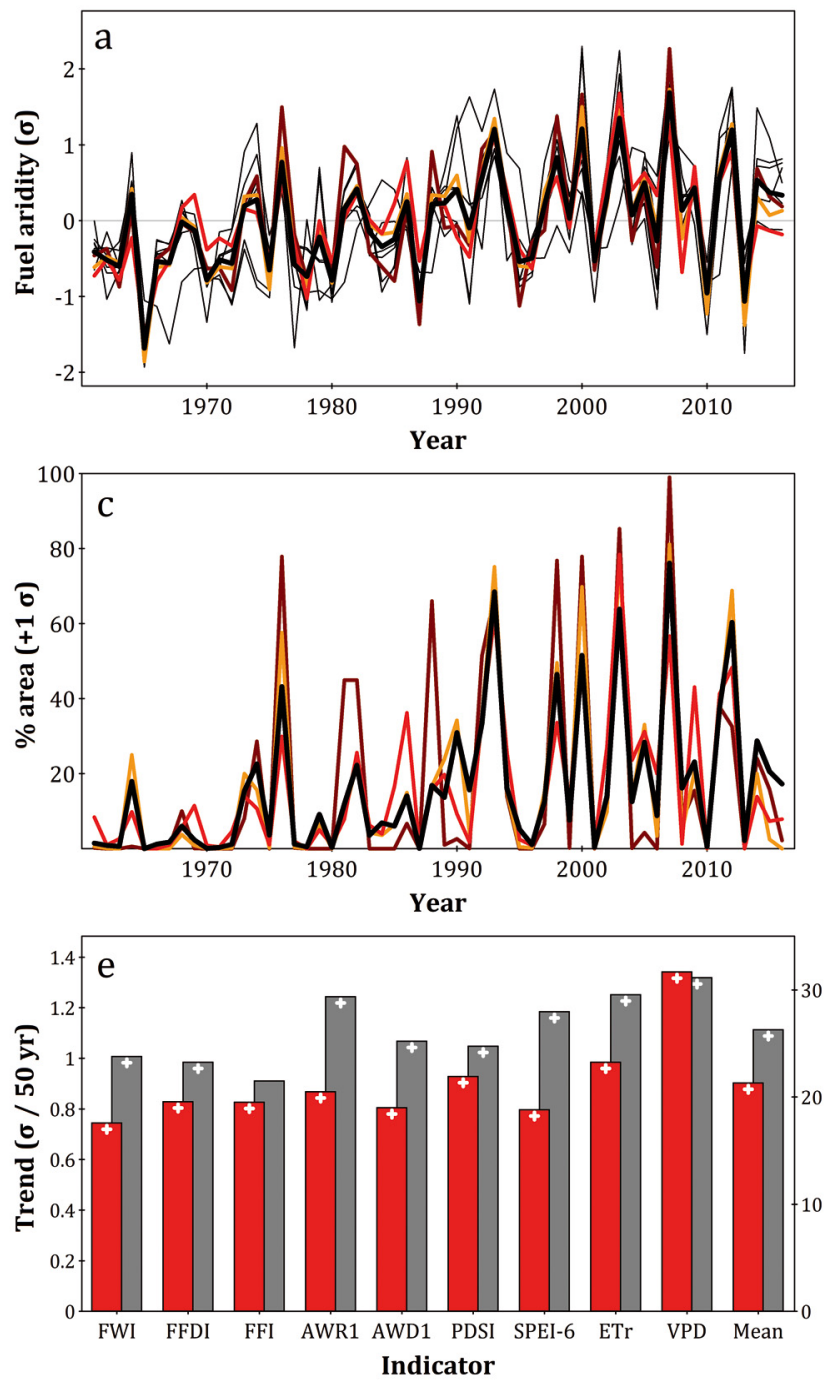

July - September
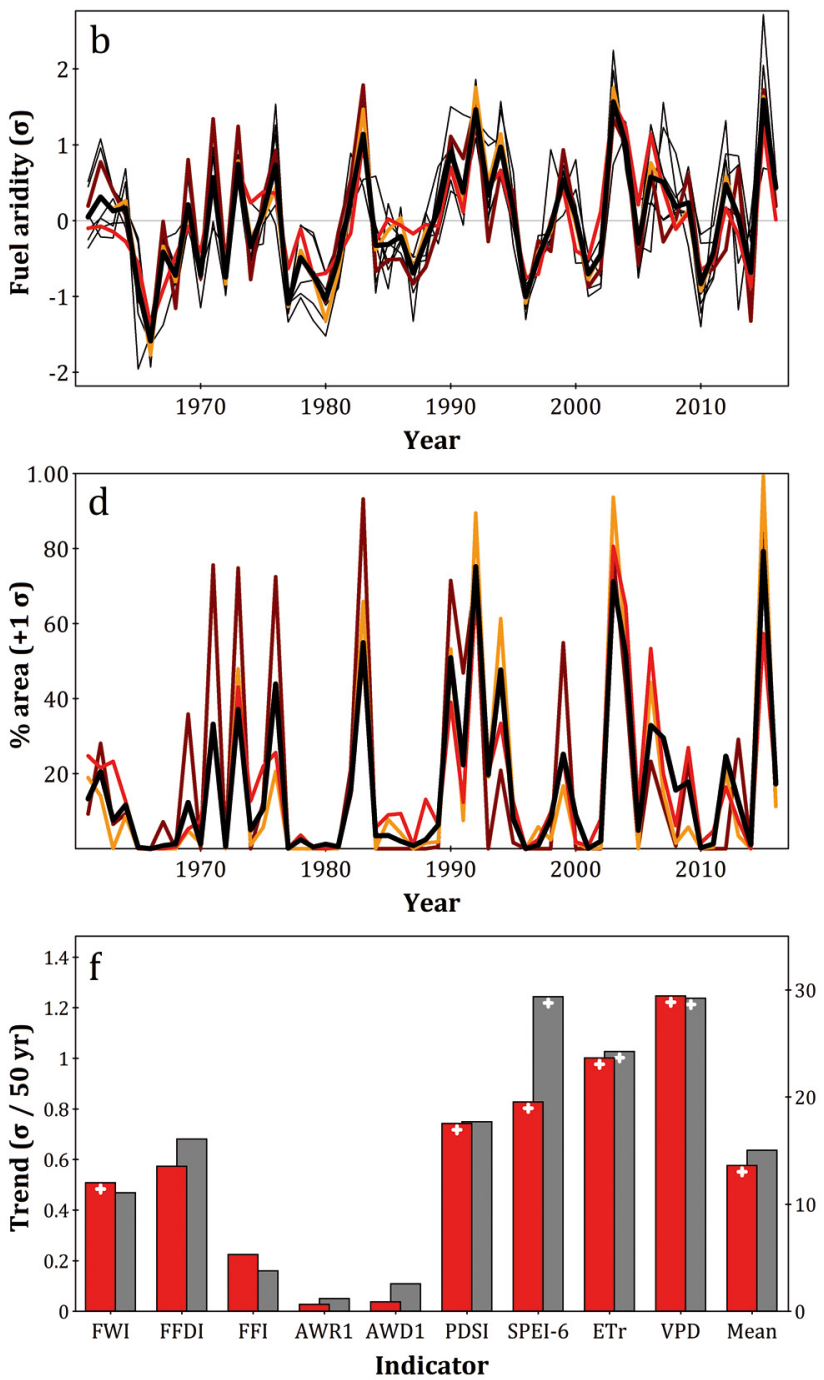

Fig. 4. Same as Fig. 3 but for peri-urban zones of the 3 largest cities (Prague, Brno and Ostrava; Fig. 1a)

recorded wildfires and a comparatively low number of days with suitable fire weather. They included reserves located in the southwest of the country (NP Šumava, PLAs Šumava, Třeboňsko, Slavkovský les, Český les, Blanský les) and those in the higher elevations in the border regions of the country (NP Krkonoše, PLAs Beskydy, Jeseníky, Broumovsko, Jizerské hory, Lužické hory). The second group represented the majority of the reserves, where the relationship between fire weather and fire incidence varied greatly and where factors other than climate factors have quite a significant influence in relation to the number of fires. The third group included 2 reserves in the southeastern part of the country (NP Podyjí, PLA Pálava), which showed a markedly higher number of fire weather days (as much as 5 times higher than that of group 1) and a higher long-term wildfire frequency.

Interestingly, in the case of NP Podyjí, the actual number of wildfires was significantly higher than would be expected based only on the fire weather climatology, which can be explained by the influence of other factors such as the terrain and number of visitors. The fact that $75 \%$ of NP Podyjí consists of deciduous forests, which are considered less susceptible than coniferous stands to fire, indicates that the increasing risk of wildfire-conducive weather will likely not be solved by a simple switch from coniferous to deciduous stands.

When we analyzed the temporal dynamics of the 9 fuel aridity metrics for April-June for the 29 nature reserves, we found a significant increase in the 

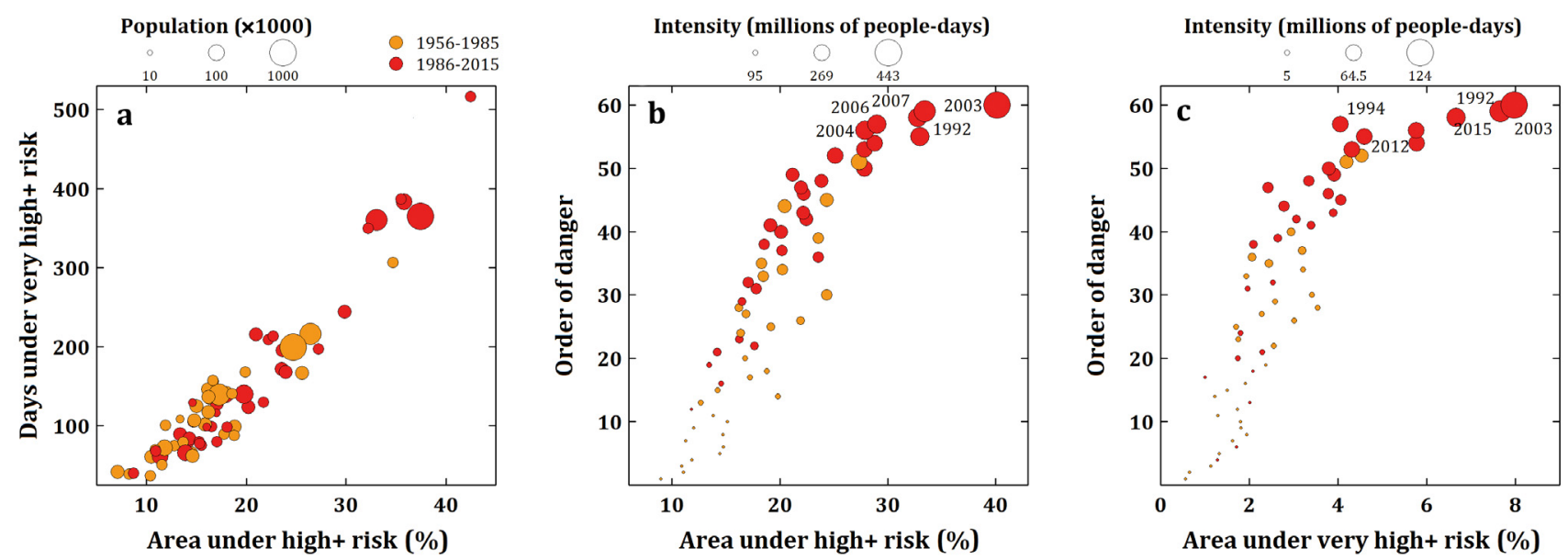

Fig. 5. (a) Area in which the peri-urban zones (Fig. 1) have been affected by high fire weather risk in the given year ( $x$-axis) and the cumulative number of days across all 36 peri-urban zones ( $y$-axis). Size of the circle indicates number of inhabitants affected; (b) order of years according to exposure of the population to high-risk fire weather conditions based on the periurban zone under high risk. Size of the circle indicates exposed number of inhabitants; (c) same as (b) but for weather conditions with a very high risk of wildfire. High+ and very high+ risk represent days with wildfire weather risk at the indicated levels (or higher) as based on Table 1. Note: Number of inhabitants was considered to be constant in both periods based on 1980 and 2010 census data

1956-2015 period, with a linear trend of $0.5 \sigma$ in the all-metric mean (Fig. 6a). Seven of the 9 aridity metrics showed a marked and significant shift toward fire-conducive conditions over the period. The allmetric mean for July-September still showed a tendency toward more aridic conditions but was far lower and not significant at the 0.05 significance level. The long-term fuel aridity metrics SPEI-6 and PDSI did not show significant trends in either time period, but the ETr and VPD experienced significant increases in both parts of the summer half-year (Fig. 6e,f). All 3 dedicated fire weather indices (FWI, FFDI and FFI) exhibited significant increases in April-June, while the increases in July-September were not found to be significant (Fig. 6e,f). If we consider the nature reserve area affected by high fuel aridity, we observe a notable increase, especially during April-June. The area of nature reserves with high aridity has been increasing steadily at a rate of $3 \%$ per decade during April-June (Fig. 6e) and 1\% per decade during July-September (Fig. 6f). Significant positive trends were observed in the area with high fuel aridity during April-June for all metrics (Fig. 6e,f), except for SPEI-6 and PDSI, which represent long-term drought indicators. For July-September, only 2 of the 9 metrics (ETr and VPD) showed significant trends, with neither of the dedicated fire indices being close to the 0.05 significance level.

However, there were great differences between individual reserves, and these differences were greater than those seen between individual peri-urban zones. We compared the fuel aridity metrics in 2 NPs on the southern border of the country, i.e. NP Šumava (Fig. S1) and NP Podyjí (Fig. 7). While the former showed no significant change in fire-risk weather conditions in either of the analyzed seasons, except for the VPD and ETr during April-June, the latter displayed a sharp warning regarding increasing aridity. The described trends not only hold in comparison to Fig. 6 but are also more intense. In particular, the increase in area with high fuel aridity indicates a significant increase of more than $6 \%$ per decade for April-June and 3\% per decade for JulySeptember. We analyzed the area affected by high fuel aridity within NP Podyjí over a 60 yr period, which increased by more than $35 \%$. Almost the entire area of this NP experienced high fuel aridity conditions at least 6 times between 2000 and 2015 (Fig. 7c,d).

We then analyzed how the exposure of the nature reserves to the fire conditions within their borders has changed over the past $60 \mathrm{yr}$ (Fig. 8). With the increasing area affected by high-risk fire weather conditions, the number of days when such situations occurred also increased (Fig. 8a). The reported trend of increasing fuel aridity (Figs. 6 \& 7) was confirmed by the absolute dominance of years from the latter part of the record, i.e. the top 6 events all occurred during the 1986-2015 period. The fire weather trends were much more pronounced in 2 southeastern reserves (NP Podyjí and PLA Pálava), but the overall data confirmed the growing exposure of valu- 

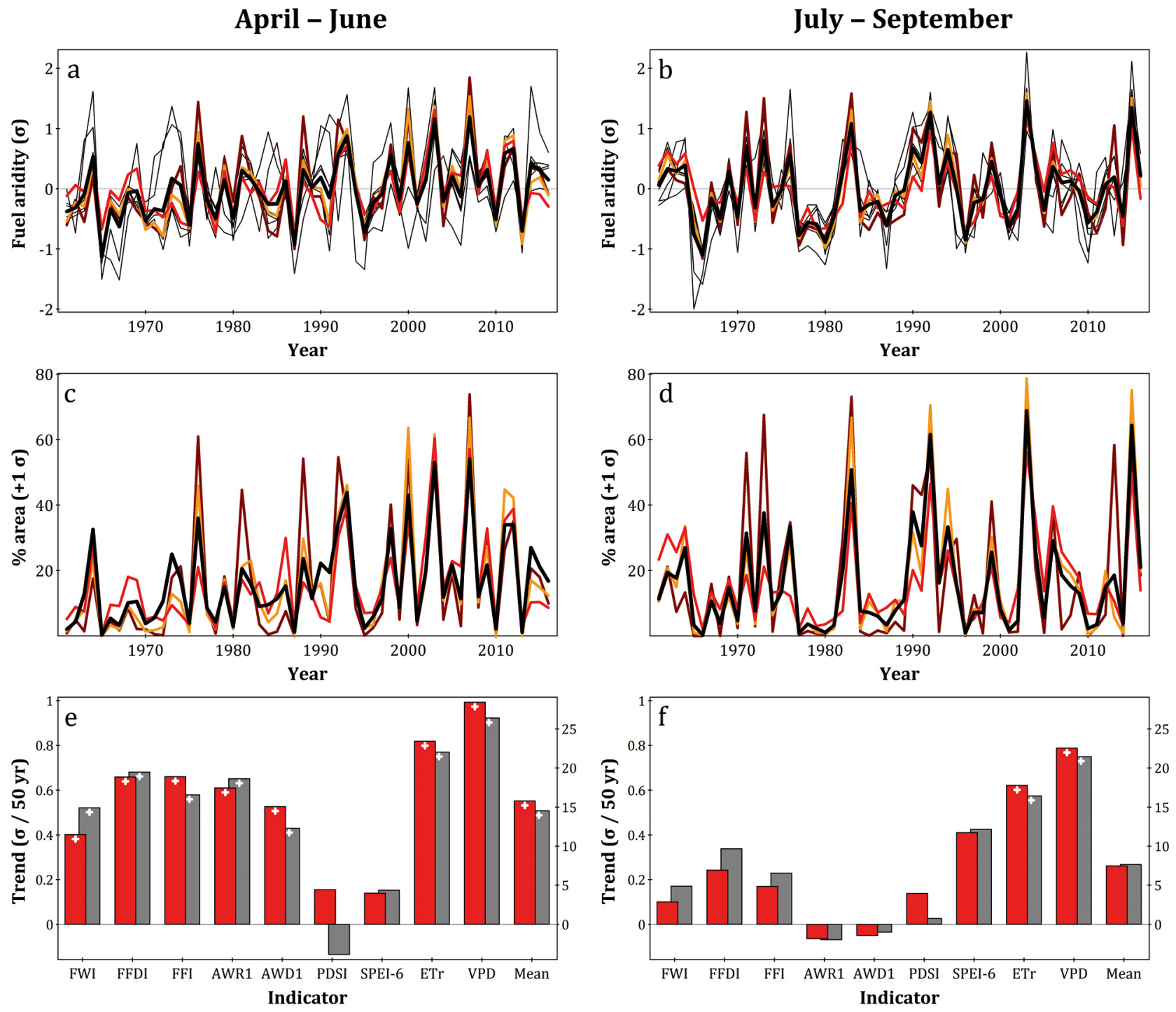

Fig. 6. Same as Fig. 3 but for nature reserves (Fig. 2a)

able nature reserves to high-risk and very high risk fire weather in 1986. Similar to peri-urban zones (Fig. 5), in the case of nature reserves, the years 2003, 1992 and 2015 stood out from the record (Fig. 8b,c) as years during which the largest part of the nature reserves showed the most suitable fire weather conditions. However, compared to the peri-urban zones, the record year was highly specific, with NP Podyjí having the highest risk in 2011 and 2012. All records for 2003 have also been exceeded in the nature reserves during the 2017-2019 drought episode.

These 2 areas also showed marked increases in wildfire-conducive weather conditions: a major decrease in the soil water content in the top layer and an increase in the number of dry and hot days (i.e. with $T_{\max }>30$ and $35^{\circ} \mathrm{C}$ ) were observed. Addition- ally, wind speed, which showed a general decreasing trend over most of the area, dropped relatively less than that observed in other regions. As a consequence, the number of wildfire-conducive days during 1986-2015 was significantly higher than that in the 1956-1985 period.

\subsection{Future fire risk under expected climate change}

\subsubsection{Climate projections}

In the peri-urban zones, the air temperature in 1986-2015 increased compared to that in 1956-1985, mostly around Brno, Ostrava and Karviná. It was observed to increase by more than $1.4^{\circ} \mathrm{C}$ in Brno. The 

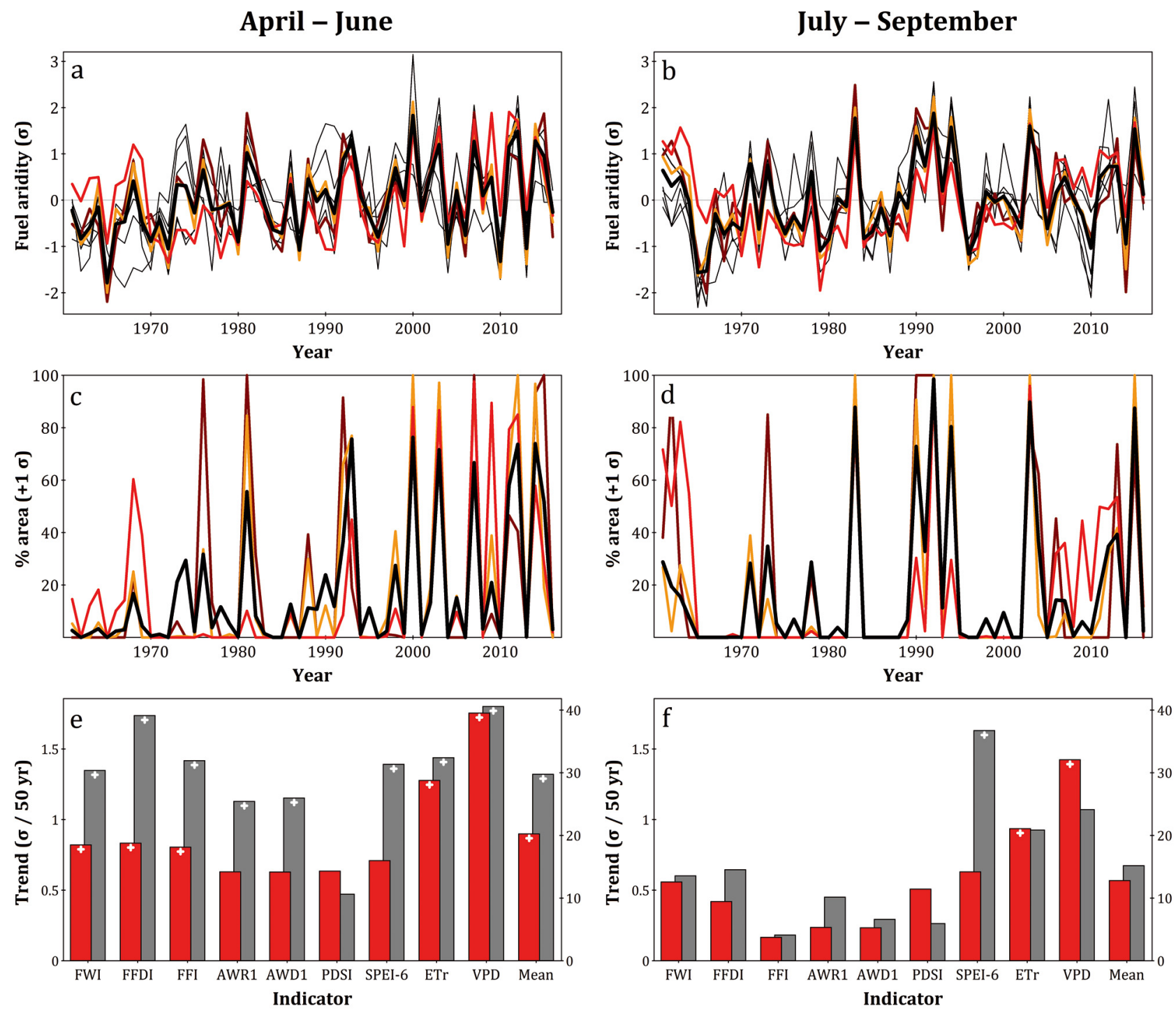

Fig. 7. Same as Fig. 3 but for NP Podyjí (Fig. 2a)

mean change in all peri-urban zones was $1.0^{\circ} \mathrm{C}$. An increase in temperature will continue in the future climate. The expected air temperature will be $2.2^{\circ} \mathrm{C}$ higher in the 2041-2060 period than in the 19561985 period in the summer half-year (April-September). The change will be highest in the peri-urban zone of Brno and in the northeast of the republic (Ostrava). Mean April-September precipitation sums of all peri-urban zones are unchanged in the current climate. However, variability in the long-term trend prevails. In the peri-urban zones of the largest cities, there was a recorded increase in precipitation in Brno $(6 \%)$ and a decrease in Ostrava $(-4 \%)$ in the comparison periods of 1986-2015 and 1956-1985. In the future, models do not predict a significant change in precipitation figures in these study areas. The increase in the summer half-year precipitation sums in the 2041-2060 period is only approximately $1 \%$. In the case of the largest cities of Prague and Brno, there is an increase in precipitation in their periurban zones of approximately $3 \%$ relative to the value during the 1956-1985 period.

The mean April-September temperature in the NPs and PLAs is approximately $1.3^{\circ} \mathrm{C}$ lower than that in the peri-urban zones. However, the increase in temperature in the current climate is the same $\left(1^{\circ} \mathrm{C}\right)$. A relatively minor change occurs in the 2 largest NPs, Krkonoše and Šumava (only approximately $0.6^{\circ} \mathrm{C}$ ). In contrast, the highest change in air temperature in the 1986-2015 period relative to the value in 1956-1985 occurred in the third-largest NP, České Švýcarsko $\left(1.3^{\circ} \mathrm{C}\right)$, and in PLA Beskydy $\left(1.5^{\circ} \mathrm{C}\right)$. The expected air temperature in the summer half-year will be $2.3^{\circ} \mathrm{C}$ higher in the $2041-2060$ period than in 

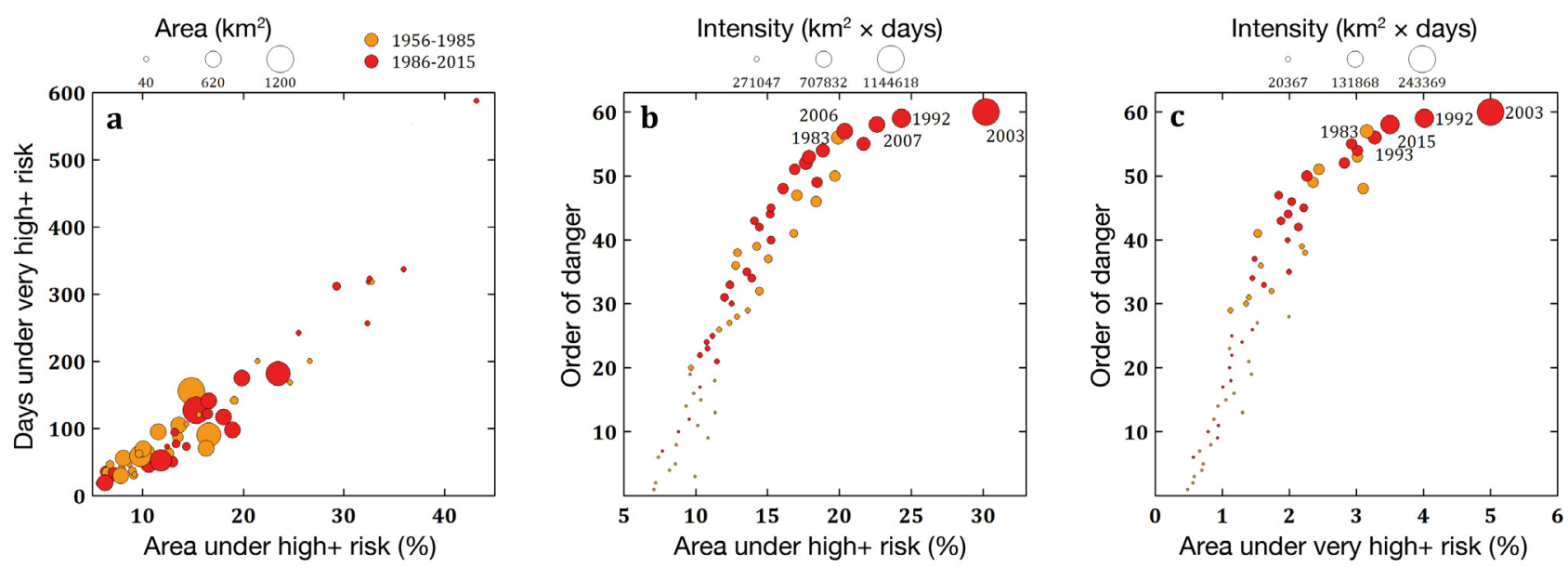

Fig. 8. (a) Area of the nature reserves (Fig. 2) that has been affected by high fire weather risk in the given season ( $x$-axis) and the cumulative number of days across all natural protected areas ( $y$-axis). Size of the circle indicates the area of the reserves affected; (b) order of years according to exposure of nature reserves to high-risk fire weather conditions based on the area of reserves under high-risk weather conditions. Size of the circle constitutes the product of the exposed area and the number of days; (c) same as (b) but for weather conditions with a very high risk of wildfire. High+ and very high+ risk represent days with wildfire weather risk at the indicated levels (or higher) as based on Table 1. Note: Area of the nature reserves was considered to be constant and refers to 2015

the 1956-1985 period. The changes are similar to those in the peri-urban zones. The April-September precipitation measured in the NPs and PLAs is approximately $12 \%$ higher than that in the peri-urban zones. The reason for this difference is that many areas are located at higher altitudes. In the current climate, we observe no statistically significant change in the overall totals of all analyzed nature reserves; however, spatial differences are visible. In the largest NP, Šumava, there was a decrease in precipitation of approximately $3 \%$ in the 1986-2015 period relative to the 1956-1985 period. In contrast, in the third- and fourth-largest NPs, České Švýcarsko and Podyjí, respectively, the precipitation in April-September is approximately $4-6 \%$ higher. Under future climate conditions, the April-September precipitation will be similar to the current climate in natural areas. The largest change in the NPs will occur in NP České Švýcarsko (10\%) in the period 2041-2060, and the largest change in the PLAs will occur in PLA Jizerské hory $(10 \%)$.

\subsubsection{Changes in fire weather in peri-urban areas and nature reserves}

As follows from Figs. 3, 4, $6 \&$ 7, the FWI, FFI and FFDI showed very similar behavior to the mean of all 9 wildfire weather metrics. All 3 fire weather indices were applied to depict the expected changes in the future wildfire weather climatology. Fig. 9a,b indi- cates that the occurrence of days with high fire risk will very likely increase during the 21st century, when aggregated over all peri-urban areas or in the vicinity of the 3 largest Czech cities. Four of 5 representative RCMs indicate a statistically significant increase compared to the 1986-2015 reference period, and even more pronounced changes are projected for the GCMs. The only exception was the FFDI results based on the RCM projections, which showed an increasing risk of wildfires, which was, however, not significant for the first evaluated period (2021-2050). For days with a very high fire risk, the increase was indicated for all $5 \mathrm{RCMs}$ and all 5 GCMs and led to a risk that was twice as high as that in the 1986-2015 period for the FWI and FFI. The increase in the number of very high risk fire days and the changes in the fire weather are different in the case of large cities that already show a relatively high probability of wildfire-conducive weather conditions under the current climate. Therefore, in these cases, the expected change tends to be smaller than that in all peri-urban zones (Fig. 9b). However, the changes are still very relevant, especially due to the marked and persistent increase in high-risk weather conditions and the marked increase in the extremity depicted by the increased values of the upper quartile and 95th percentile.

Most of the nature reserves are situated at higher altitudes with more ample and reliable rainfall; therefore, the occurrence of fire-conducive weather conditions under the current climate is less frequent 


\section{a Cities}

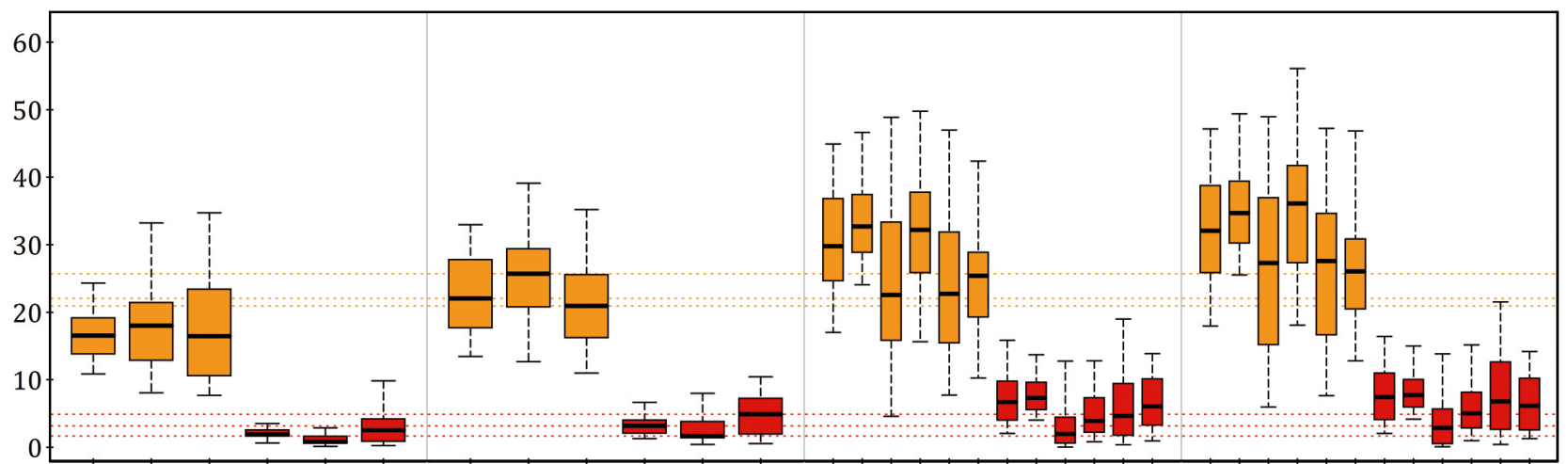

\section{b Big Cities}

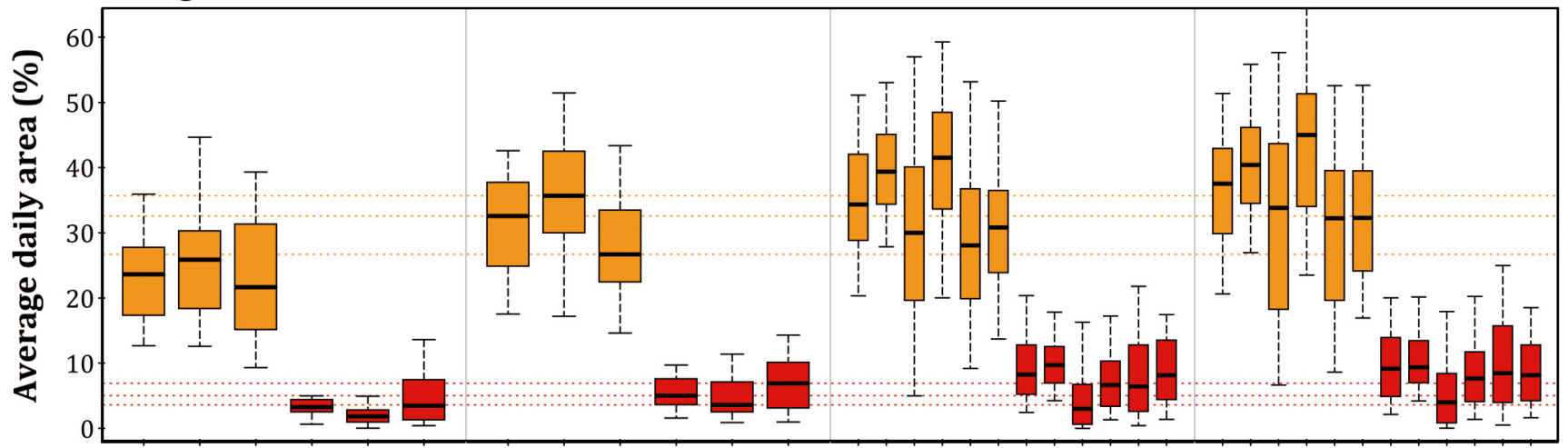

C Protected Areas

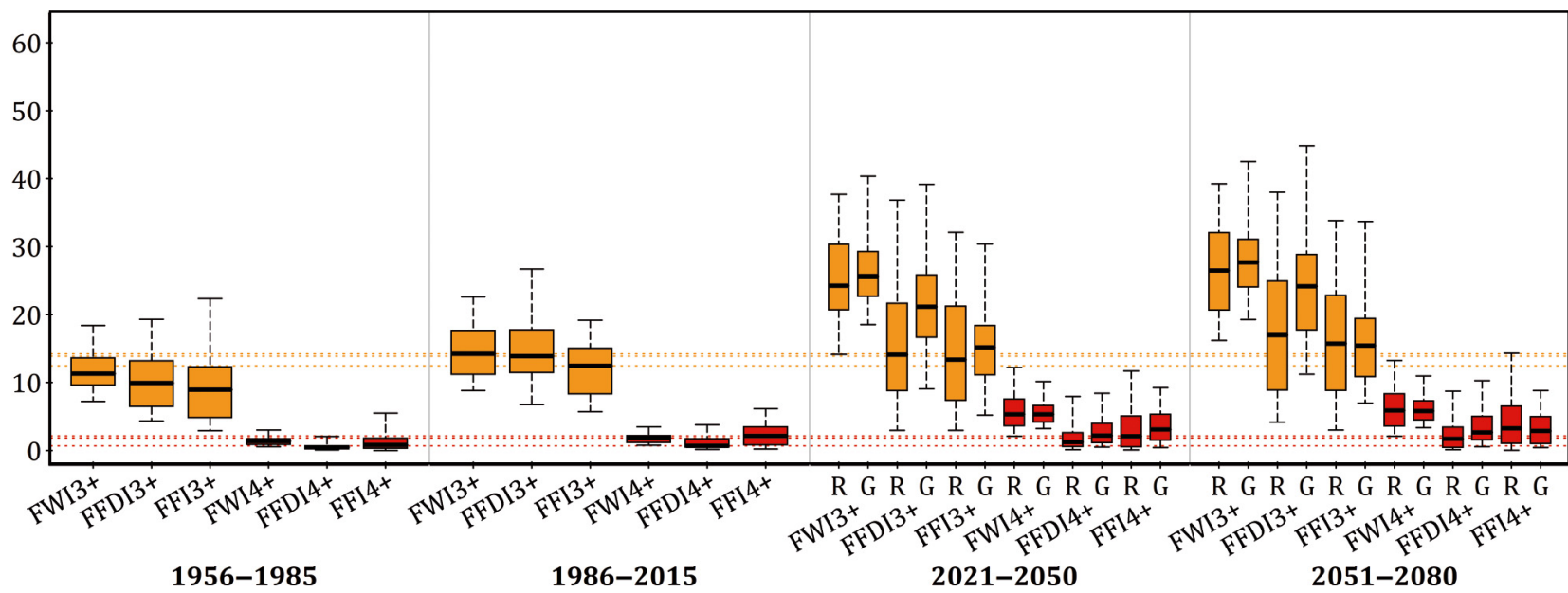

Fig. 9. Area affected by April-September fire weather in the categories of high and above (FD3) and very high and above (FD4), as assessed by the FWI, FFDI and FFI for (a) the peri-urban zones of the 36 largest cities and towns, (b) the 3 largest cities (Prague, Brno and Ostrava) and (c) the national parks and protected landscape areas for the 2 reference periods of 1956-1985 and 1986-2015 and for 2 periods of 30 yr until 2080. Future values are based on estimates of 5 RCMs (R) and 5 GCMs (G) for RCP4.5. Box plots express the median, lower and upper quartiles and 5th and 95th percentiles. Dotted lines delineate the median for each category during the 1986-2015 period. FD: fire danger; other abbreviations as in Fig. 3

than that in the peri-urban zones (Fig. 9a-c). However, with progressing climate change, the climate becomes more favorable for the occurrence of highrisk and very high risk events. This change would constitute a step change according to the FWI and
FFI values compared to the 1986-2015 baseline. Again, in the case of the FFDI, the increase in the affected area is quite significant when downscaled GCM data are used compared to the FFDI estimates calculated using the RCM-based climate data. 


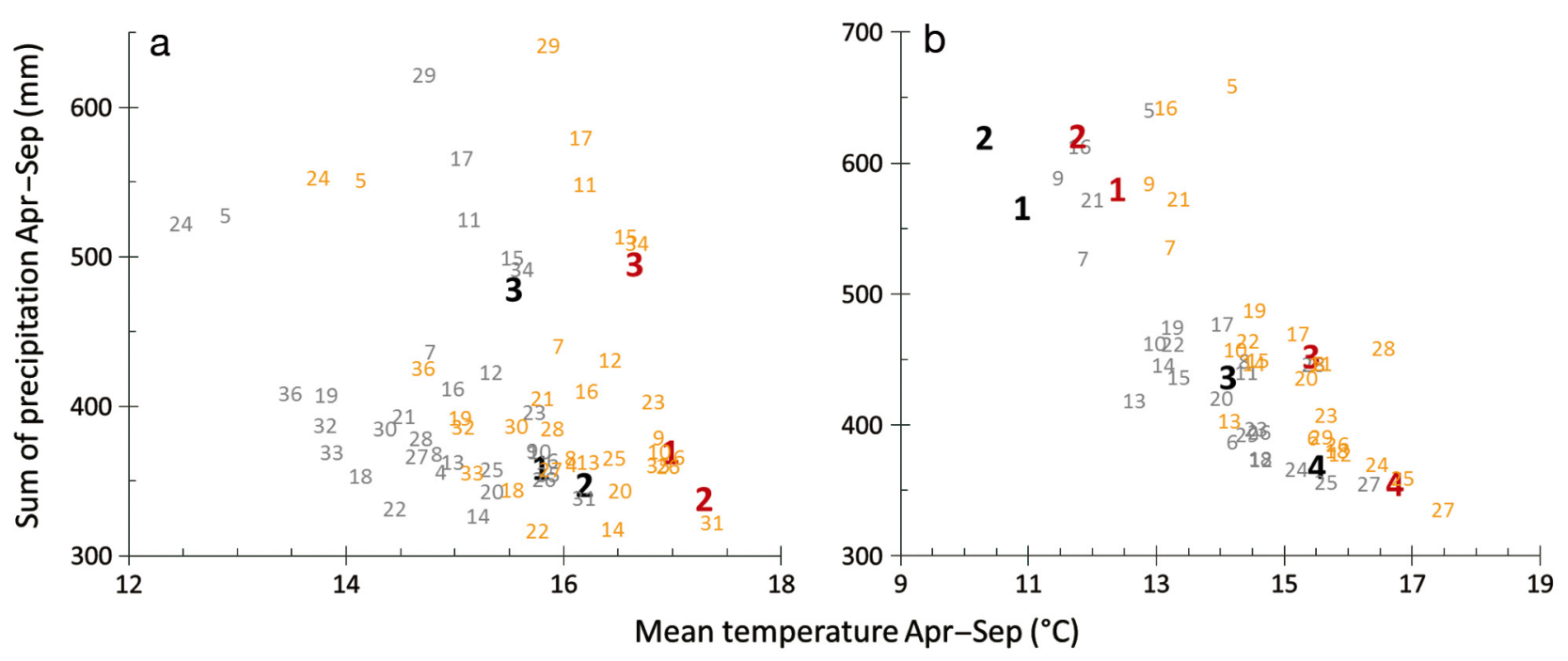

Fig. 10. April-September temperature and precipitation for the (a) 31 peri-urban zones and (b) 4 national parks together with 25 landscape protected areas (for numbers, see Figs. 1 \& 2, respectively). Gray numbers depict values for the 1956-1985 period, and orange numbers represent the best estimate for the 2041-2060 period. Highlighted numbers depict the 3 largest cities (a) and 4 national parks (b) as listed in Tables S1 and S2, respectively

When the projected area affected by the occurrence of high or very high risk fire weather was assessed using projections based on 5 representative GCMs (Fig. S2), the signal was much more uniform than in the case of the RCMs. However, the results were very similar to those projected based on the RCMs. It is also worth noting that the largest increase in the occurrence of wildfire-conducive weather conditions is likely to occur within the next 3 decades (2021-2050). While the shift in the peri-urban zones will be of similar magnitude to the change between 1956-1985 and 1986-2015, in the case of natural reserves, the shift will be far more pronounced.

Overall, there are marked differences between the 5 RCMs representing a wide range of climate variability, but even the RCM with the lowest projected change in fire weather leads to an increased occurrence of fire weather days compared to the number in the 1986-2015 period. There are also considerable regional differences. The same conclusions can be deduced for the changes expected according to the 5 tested GCMs, but here, the rate of change is markedly higher (Fig. S2).

\section{DISCUSSION}

\subsection{Observed impact of wildfires}

The sensitivity of the peri-urban areas is high compared to that of the entire territory of the Czech Republic, with not only marked fire weather trends
(Fig. 9) but also pronounced changes expected under the future climate (Fig. 10). The peri-urban areas do not serve only as recreational grounds; they also usually provide a place for some of the critical infrastructure, e.g. power lines, municipality water tanks and/or waste water treatment plants, which could be adversely affected. Price \& Bradstock (2014) analyzed natural fires in Sydney's suburbs in Australia. They found that urban centers provide both sources of ignition and a degree of protection from fire spread. Fire activity culminated in areas where urbanization has occurred but where much of the original vegetation remained. A higher rate of fire was registered in relatively urbanized areas with remnants of natural forest vegetation, and the rate was lowest in farmland. Clearly, the change in the fire weather conditions themselves or prolongation of the fire season does not automatically lead to the increase in fire frequency. For example technological changes and better awareness of the population have been show to stem the growth of fires (Wastl et al. 2012). On average, $89.5 \%$ of all vegetation fires in the Czech Republic were recorded in the countryside and only $10.5 \%$ in forests during the 1971-2015 period (Možný et al. 2020), with the same authors pointing out that only $1 \%$ of fires had a natural cause (most often lightning). Small and medium fires with an area in the dozens of square meters with a duration in hours prevailed. On the other hand, higher human activity in the countryside is according to Možný et al. (2020) reflected in the higher frequency of vegetation fires. This study found that 
more than $65 \%$ of wildfires in the Czech Republic are being recorded during the harvest periods. Also, ongoing changes in the Central European landscape and suburbanization cannot be omitted. Možný et al. (2020) showed that near those cities where an increase in population and building activity has been reported in the past 2 decades, growth in the frequency of wildfires followed.

Wildfires occurring near urban areas threaten lives and property. Wildfires cause direct losses, such as deaths, injuries and health impacts; damage to buildings and infrastructure; environmental impacts; and losses in agriculture and forestry. Indirect losses include general economic impacts, evacuation costs, service interruptions and trade impacts. In addition, wildfire smoke contains many air pollutants, such as carbon monoxide, nitrogen dioxide, ozone, particulate matter, polycyclic aromatic hydrocarbons and volatile organic compounds (Naeher et al. 2007). Reid et al. (2016) found consistent evidence of associations between wildfire smoke exposure and respiratory morbidity in general and specifically for exacerbations of asthma and chronic obstructive pulmonary disease. Growing evidence suggests associations with respiratory infections and all-cause mortality. Smoke from the wildfires in California in 2018 was associated with asthma attacks and heart problems and contributed to a decline of the air quality. Smoke from fires primarily affects the local community, but it can affect people who live dozens of kilometers away from the fire. Firefighters extinguished the largest forest fires in the Czech Republic within a few days; thus, there were only short-term health complications in the population, which mainly consisted of respiratory problems. In the case of fires in the wildland-urban interface (WUI), however, mixing or even reacting with urban or even industrial pollutants may occur, which may cause more serious health problems (Hon et al. 2010).

Forest fires were historically frequent, as identified by soil charcoal ${ }^{14} \mathrm{C}$ dating. However, a marked decrease in fires was observed since ca. $6200 \mathrm{yr}$ BP as a result of the transformation of forest vegetation from being dominated by conifer (Picea abies) to mixed (Fagus sylvatica-Abies alba) forest (Bobek et al. 2018). Most of the forests in natural protected areas were transformed to commercial stands dominated by Norway spruce P. abies or Scotch pine Pinus silvestris during the last 2 centuries. This transition increased the fire risk, mostly in the NPs Podyjí and České Švýcarsko with lower elevations. However, restoration management (NP Podyjí) or ongoing widespread bark beetle Ips typhographus infesta- tions in NP České Švýcarsko and in the lower elevations of the Krkonoše and the Šumava mountains significantly decreased the number of coniferous stands. These stands will be replaced (naturally or by management) by broadleaf-dominant naturally closed stands. Additionally, future drier and warmer climates will support broadleaf stands rather than coniferous stands, and this change may result in a lower fire risk in protected areas. However, as Fig. 2 shows in the example of NP Podyjí, even areas dominated by deciduous stands are highly susceptible to fire occurrence. Expected vegetation changes must be considered in the projected future scenarios of fire risk.

Recent experience with the observed high fire frequency and extent of wildfires in Sweden demonstrates that under extreme fire-prone weather conditions, the spread of fire may have no association with peri-urban zones but is linked to locations with flammable material such as forest areas. Over 25000 ha of forest fires were recorded in 2018, which was approximately 10 times higher than the mean in the 21st century; however, these fires had minimal, if any, impacts on inhabited areas, properties and traffic infrastructure (SOU 2019). Despite the large areal extent of these fires requiring the deployment of international aid to combat them, the situation fortunately had only a limited impact on the local population, with only approximately a few hundred temporarily evacuated residents. The resulting damage was generally in the form of a loss of economic value (e.g. negatively affected growing stock, increment and other ecosystem services) of forests and the additional costs associated with the necessary sanitary measures and forest regeneration.

\subsection{European context and impacts}

As a direct consequence of fire, carbon dioxide $\left(\mathrm{CO}_{2}\right)$, nitrous oxide $\left(\mathrm{N}_{2} \mathrm{O}\right)$, methane $\left(\mathrm{CH}_{4}\right)$ and other combustion gases are released into the atmosphere (e.g. Omi 2005). The indirect damage to forest and agricultural crops and soil in particular is difficult to quantify, and in many cases, it is difficult to identify and is therefore often overlooked or downplayed. In the case of forest fires, if all vegetation (terrestrial and crown fire) is affected, all layers of the forest community are destroyed, both its phytocomponents and large zoocenosis, and the soil environment is significantly influenced. A large forest fire can remove all vegetation soil cover, detritus and humus. The exposed soil is threatened by erosion, especially 
where the soil-forming substrate has been disturbed. Washed-away soil particles can initiate the overgrowth of the burrowing area and complicate restoration of the forest. Other negative factors may be secondary biotic hazards, such as the destruction of insect pests after recovery. For agricultural land, the indirect consequences of a wildfire are usually much easier to address quickly due to the availability of more intensive management options.

In the conditions of Central Europe, large forest fires have been generally infrequent. However, if large wildfires arise, they often affect protected areas. For example, in March 2017, a wildfire of 145 ha occurred in a Natura 2000 site in the Czech Republic (San-Miguel-Ayanz et al. 2018). The nature reserves in the country are often represented by unmanaged areas with structurally rich forests. These forests are characterized by having higher amounts of flammable material than the more common commercial forests that are typically composed of even-aged and closed canopies, without shrub layers and a limited amount of dead wood on the ground (Vítková et al. 2018). Nonetheless, the Czech landscape, specifically its forests, is currently facing an unprecedented decline in coniferous forest stands due to the extreme drought conditions observed in recent (2015-2018) years (Ministerstvo zemědělství 2019) as well as the associated bark beetle outbreaks (www.kurovcoveinfo.cz). This situation leads to more pronounced fire risk, with numerous forest locations with dry wood harvest residues, dead trees and generally an increased load of flammable material on the temporarily untreated affected forest areas due to inadequate technical and personnel capacities in the country.

For example, the recent situation in Sweden demonstrates that the rapid increase in wildfire frequency and extent of burned areas is very likely in areas that were previously only infrequently endangered by fires (SOU 2019). In 2018, more than 25000 ha and almost 3 million $\mathrm{m}^{3}$ of wood were destroyed by fire in Swedish forests despite international aid provided to combat the forest fires there. It should be noted that the month of July 2018 has never been as hot since the collection of Swedish weather data began $260 \mathrm{yr}$ ago. Interestingly, the ignition factor of some of the largest wildfires in 2018 was sparks from trains and lightning (SOU 2019).

In Central European countries, the relative frequency of deliberate and negligent fires is largemore than $80 \%$ of fires were due to human causes (Ganteaume et al. 2013, Kula \& Jankovská 2013). Many authors have shown that the frequency of fire ignitions can be explained by spatially explicit variables such as distance to roads, railways, power lines and urban areas or population density (Martínez et al. 2009, Padilla \& Vega-García 2011, Ganteaume et al. 2013, Adámek et al. 2018). Peri-urban zones are naturally highly frequented by humans; therefore, there is a very high probability of ignition in periods with high fuel aridity. Wildfire occurrence was controlled mostly by environmental factors, while wildfire frequency was strongly driven by human factors in the Czech Republic (Adámek et al. 2018). The coincidence of high-risk fire weather and high density of human activities as a ubiquitous ignition trigger can lead to the intensive growth of wildfire frequency and risk in peri-urban zones.

In Central Europe, forests and other natural or seminatural lands are very fragmented. The typical rural landscape pattern is where forest is intermingled with agricultural and artificial lands. Most forest edges are artificial, i.e. bordering areas with more intensive land use. In the Czech Republic, there are ca. $85 \%$ of artificial forest edges, and ca. $40 \%$ of woodlands are within $100 \mathrm{~m}$ of other lands (Estreguil et al. 2012). Settlement structures and hierarchies are also highly fragmented in the Czech Republic. There are many small and medium-sized towns with options for individual recreation in their vicinities. With respect to natural land fragmentation and settlement structure fragmentation, the danger of wildfires is very high. Even a relatively small wildfire can threaten settlements and human lives. Therefore, the increased number of observed wildfires (Ministerstvo zemědělství 2018) represents a serious safety risk, which is at least partly mitigated by the system of professionals in rural areas and by the dense network of voluntary firefighter units.

Wildfires are also sources of greenhouse gas emissions (including $\mathrm{CO}_{2}, \mathrm{~N}_{2} \mathrm{O}$ and $\mathrm{CH}_{4}$ ), but these have not yet been considered as an important issue in the Czech national emission inventory report (Czech Hydrometeorological Institute 2019). Their contributions to overall emissions remain limited in the conditions of the country, representing just over $70000 \mathrm{t}$ $\mathrm{CO}_{2}$ equivalent per year since 1990. The highest emission contribution from wildfires was observed in 1997, when a burned area of nearly 3500 ha released approximately 400000 t CO$_{2}$ equivalent (Czech Hydrometeorological Institute 2019). This value is still much lower than that observed for the fire-prone southern European countries or the continental part of the Russian Federation, where wildfires represent a key emission category (National Inventory Reports, https://unfccc.int/). This scenario will, however, also 
likely be the case for the fire-intensive years observed in other European countries, such as in Sweden in 2018, as discussed above.

\subsection{Adaptation and mitigation of fire risk under climate change}

\subsubsection{Peri-urban zones}

Suburban areas are where the use of urban land is in contact with the wild landscape, and these areas are referred to as the WUI. Changes in land use in many countries over recent decades have led to the growth of WUI areas. There are more sources of ignitions, which increase the vulnerability of WUI areas (Calkin et al. 2014, Radeloff et al. 2018). The basis for the risk assessment is detailed WUI mapping. In the USA, the WUI is defined by house density and vegetation per square kilometer. In contrast, different approaches for mapping and definition of the WUI typology are used in Europe (Modugno et al. 2016).

Within the Czech Republic, the municipalities establish voluntary fire brigade units and provide for the construction and maintenance of fire protection buildings and fire safety, namely, for its territory requirements by Law No. 133/1985. Municipalities declare the fire regulations and ensure fire prevention in their territory. However, considering the results of this study, the WUI area must adapt to the increased frequency of natural fires to reduce their future vulnerability. It is important to increase the adaptive resistance of WUI areas against wildfire. The basis is the creation of regional maps of threats to wildlife in individual WUI areas. The specific degree of risk will depend on the factors of climate, landscape, forest and relief, transport and water resource availability and on the presence of hazardous and highly flammable industrial facilities in open spaces. In the most vulnerable areas, there is a need to regulate housing construction and the operation of industrial sites. In the Czech Republic, typological maps of wildfire risks should be created by regional self-government for individual WUIs. This process will require financial support from state authorities. The methodology for typological risk of wildfire mapping varies from country to region (Lampin-Maillet et al. 2010a,b, Galiana-Martin et al. 2011).

While the present study covered the peri-urban zones and therefore critical infrastructure in its immediate vicinity (Section 4.1), the way the peri-urban zones were defined does not allow for inclusion of the entire critical infrastructure. Therefore, wildfire risk for key water reservoirs and power stations that could be affected by the occurrence of wildfires have not been specifically included in the study.

\subsubsection{Nature reserves}

The current practice on active and passive fire protection in nature reserves imposes a common obligation that everyone shall extinguish fire if possible or realize measures necessary for preventing fire spread. This law applies equally to all lands, including areas with the highest protection level, i.e. the nature reserves. In practice, specific prevention measures are taken by the local management of protection areas. For example, NP Šumava, located along the border with Germany and Austria, established its own fire prevention unit and road access maintenance system. This is similar to the practice in the neighboring NP Bavarian Forest in Germany, which uses a fire prevention system aided by airborne techniques (helicopters) and a network of water reservoirs. Although occasionally debated in the context of nature reserves and their regime (strictly unmanaged areas), forest fire prevention is generally always prioritized over other environmental interests in European conditions (San-MiguelAyanz et al. 2018). The important argument for the forest fire prevention practice adopted in nature reserves is the fact that artificial anthropogenic factors largely dominate over natural causes as ignition factors (Kula \& Jankovská 2013, Adámek et al. 2018); hence, forest fires cannot be regarded as a part of natural processes. On the other hand, some recent studies have shown that fires have been a part of Central European forest ecosystems, but information about frequency, size or causes is still only fragmental (Rösch 2000, Carcaillet et al. 2009, Niklasson et al. 2010). The detailed reconstruction of the Białowieża Primeval Forest fire history identified that fire was a major component in the past dynamics of this forest, but the human influence on the fire regime was probably substantial (Niklasson et al. 2010).

\subsubsection{Early warning systems}

As results presented in this study as well as results of Trnka et al. (2020c) have shown, the FWI and FFDI fire weather indices seem to well explain the interannual as well as seasonal variability in the number of wildfires. As the risk of weather conditions condu- 
cive to wildfire occurrence has been growing, and this trend is likely to continue over the coming decades (e.g. Fig. 9 and Fig. S2), the results of this study have been implemented into the operational fire weather forecasting system (www.firerisk.cz) as 1 concrete adaptation measure that should, through as accurate a fire weather forecast as possible, at least partly counterweigh unfavorable trends in weather conditions. Besides the FWI and FFDI fire weather indices, the forecasting system also employs the Haines Index to estimate the immediate favorability of weather conditions to wildfire spread as shown e.g. by Tatli \& Türkeş (2014).

\section{CONCLUSIONS}

We tested changes in the 9 weather-based predictors that are considered to be related to wildfire risk in peri-urban zones and nature reserves. Based on observed data over the Czech Republic, we have shown considerable changes that are coherent with increasing wildfire risk, especially in April-June during the 1956-2015 period. This result is significant because some of the fire weather indicators were shown to reflect the observed probability of wildfire occurrence both in peri-urban zones and in nature reserves based on the 1971-2015 wildfire database. A significant increase in the area affected by weather conditions that are highly conducive to wildfires is expected over the coming decades. While the risk of wildfires during 1956-2015 was mostly in the lowlands and peri-urban zones of the lowest-lying towns, the risk will increase more dramatically between 2020 and 2080 for nature reserves and periurban zones at higher elevations and will remain high in the lowland areas and peri-urban zones of the largest cities.

We have shown that while the methods for assessing weather conducive to wildfires differ in their complexity, they show the same overall trend. Although the Czech Republic and all of Central Europe in general are not currently considered a wildfire hotspot in comparison with the Mediterranean area (given the usual fire extent, dedicated resources or public perception), this situation will likely change with the projected increases of dangerous fire weather. This change will inevitably require complex changes in preparedness (in both operational capabilities and policies) in the case of a wildfire occurrence in peri-urban zones as well as the strategy of dealing with wildfires within protected areas. This adjustment will require a significant upgrade of existing strategic and urban planning to account for such an increase in wildfire risk as well as changes in the legal framework on the national level that would enable a more flexible approach to wildfires within protected areas.

Acknowledgements. The authors thank 2 anonymous reviewers and Prof. Jörg Matschulat for helpful comments and recommendations that improved the study. The analyses were conducted with the support of SustES, Adaptation strategies for sustainable ecosystem services and food security under adverse environmental conditions (CZ.02.1.01/ 0.0/0.0/16_019/0000797). P.S. was supported by the ERA4 CS SERV_FORFIRE project.

\section{LITERATURE CITED}

Abatzoglou JT, Williams AP (2016) Impact of anthropogenic climate change on wildfire across western US forests. Proc Natl Acad Sci USA 113:11770-11775

Abatzoglou JT, Williams AP, Boschetti L, Zubkova M, Kolden CA (2018) Global patterns of interannual climate-fire relationships. Glob Change Biol 24:5164-5175

Adámek M, Bobek P, Hadincová V, Wild J, Kopecký M (2015) Forest fires within a temperate landscape: a decadal and millennial perspective from a sandstone region in Central Europe. For Ecol Manage 336:81-90

Adámek M, Jankovská Z, Hadincová V, Kula E, Wild J (2018) Drivers of forest fire occurrence in the cultural landscape of Central Europe. Landsc Ecol 33:2031-2045

Aldersley A, Murray SJ, Cornell SE (2011) Global and regional analysis of climate and human drivers of wildfire. Sci Total Environ 409:3472-3481

Allen RG, Pereira LS, Raes D, Smith M (1998) Crop evapotranspiration: guidelines for computing crop water requirements. FAO Irrigation and Drainage Paper No. 56. FAO, Rome

Andela N, Morton DC, Giglio L, Chen Y and others (2017) A human-driven decline in global burned area. Science 356:1356-1362

* Balch JK, Bradley BA, Abatzoglou JT, Nagy RC, Fusco EJ, Mahood AL (2017) Human-started wildfires expand the fire niche across the United States. Proc Natl Acad Sci USA 114:2946-2951

Bobek P, Šamonil P, Jamrichová E (2018) Biotic control on Holocene fire frequency in a temperate mountain forest, Czech Republic. J Quaternary Sci 33:892-904

* Boer MM, Nolan RH, Resco De Dios V, Clarke H, Price OF, Bradstock RA (2017) Changing weather extremes call for early warning of potential for catastrophic fire. Earths Futur 5:1196-1202

Bond-Lamberty B, Peckham SD, Ahl DE, Gower ST (2007) Fire as the dominant driver of central Canadian boreal forest carbon balance. Nature 450:89-92

Bowman DMJS, Balch JK, Artaxo P, Bond WJ and others (2009) Fire in the Earth system. Science 324:481-484

Bowman DMJS, Williamson GJ, Abatzoglou JT, Kolden CA, Cochrane MA, Smith AMS (2017) Human exposure and sensitivity to globally extreme wildfire events. Nat Ecol Evol 1:0058

* Bradstock RA (2010) A biogeographic model of fire regimes in Australia: current and future implications. Glob Ecol Biogeogr 19:145-158 
Bradstock RA, Cohn JS, Gill AM, Bedward M, Lucas C (2009) Prediction of the probability of large fires in the Sydney region of south-eastern Australia using fire weather. Int J Wildland Fire 18:932-943

Büntgen U, Brázdil R, Dobrovolný P, Trnka M, Kyncl T (2011) Five centuries of southern Moravian drought variations revealed from living and historic tree rings. Theor Appl Climatol 105:167-180

Calkin DE, Cohen JD, Finney MA, Thompson MP (2014) How risk management can prevent future wildfire disasters in the wildland-urban interface. Proc Natl Acad Sci USA 111:746-751

Carcaillet C, Ali AA, Blarquez O, Genries A, Mourier B, Bremond L (2009) Spatial variability of fire history in subalpine forests: from natural to cultural regimes. Ecoscience 16:1-12

Clarke L, Edmonds J, Jacoby H, Pitcher H, Reilly J, Richels $\mathrm{R}$ (2007) Scenarios of greenhouse gas emissions and atmospheric concentrations. US Climate Change Science Program and the Subcommittee on Global Change Research. Department of Energy, Office of Biological \& Environmental Research, Washington, DC

Cochrane MA (2003) Fire science for rainforests. Nature 421:913-919

Cruz MG, Sullivan AL, Gould JS, Sims NC, Bannister AJ, Hollis JJ, Hurley RJ (2012) Anatomy of a catastrophic wildfire: the Black Saturday Kilmore East fire in Victoria, Australia. For Ecol Manage 284:269-285

Czech Hydrometeorological Institute (2019) National greenhouse gas inventory report of the Czech Republic (reported inventories 1990-2017). Czech Hydrometeorological Institute, Ministry of Environment of the Czech Republic, Prague

* de Groot WJ, Field RD, Brady MA, Roswintiarti O, Mohamad M (2006) Development of the Indonesian and Malaysian fire danger rating systems. Mitig Adapt Strategies Glob Change 12:165-180

Dowdy AJ, Mills GA, Finkele K, De Groot W (2009) Australian fire weather as represented by the McArthur Forest Fire Danger Index and the Canadian Forest Fire Weather Index. CAWCR Tech Rep 10. Centre for Australian Weather and Climate Research, Melbourne

* Dowdy AJ, Mills GA, Finkele K, De Groot W (2010) Index sensitivity analysis applied to the Canadian Forest Fire Weather Index and the McArthur Forest Fire Danger Index. Meteorol Appl 17:298-312

* Dubrovsky M, Trnka M, Holman IP, Svobodova E, Harrison PA (2015) Developing a reduced-form ensemble of climate change scenarios for Europe and its application to selected impact indicators. Clim Change 128:169-186

Dudfield M (2004) Art and science of forest and rural fire management. In: Proc 11th Ann AFAC Conf and Inaugural Bushfire CRC Conf, 7-9 October, 2004, Perth, p 183-185

Estreguil C, Caudullo G, de Rigo D, San Miguel J (2012) Forest landscape in Europe: pattern, fragmentation and connectivity. Executive report. Joint Research Centre of the European Commission, Luxembourg

Galiana-Martin L, Herrero G, Solana J (2011) A wildlandurban interface typology for forest fire risk management in Mediterranean areas. Landsc Res 36:151-171

Ganteaume A, Camia A, Jappiot M, San-Miguel-Ayanz J, Long-Fournel M, Lampin C (2013) A review of the main driving factors of forest fire ignition over Europe. Environ Manage 51:651-662
Griffiths D (1998) Improved formula for the McArthur Forest Fire Danger Meter. Meteorological note 214. Bureau of Meteorology, Melbourne, p 11

* Harmáčková ZV, Vačkář D (2015) Modelling regulating ecosystem services trade-offs across landscape scenarios in Třeboňsko Wetlands Biosphere Reserve, Czech Republic. Ecol Modell 295:207-215

Heikinhemo M, Venäläinen A, Tourula T (1998) A soil moisture index for the assessment of forest fire risk in the boreal zone. In: Dalezios NR (ed) Proc COST 77, 79, 711 Int Symp Appl Agrometeorol Agroclimatol, Volos, 24-26 April 1996. European Commission, Luxembourg, p 549-555

* Hlavinka P, Trnka M, Balek J, Semerádová D and others (2011) Development and evaluation of the SoilClim model for water balance and soil climate estimates. Agric Water Manage 98:1249-1261

Hon Z, Patočka J, Karda L (2010) Toxikologie lesních požárů (=Toxicology of forest fires). Časopis 112:10-11

* Hůnová I, Bäumelt V (2018) Observation-based trends in ambient ozone in the Czech Republic over the past two decades. Atmos Environ 172:157-167

* Jiřík V, Machaczka O, Miturová H, Tomášek I and others (2016) Air pollution and potential health risk in Ostrava Region - a review. Cent Eur J Public Health 24:S4-S17

Johnston F, Hanigan I, Henderson S, Morgan G, Bowman D (2011) Extreme air pollution events from bushfires and dust storms and their association with mortality in Sydney, Australia 1994-2007. Environ Res 111:811-816

Jurečka F, Možný M, Balek J, Žalud Z, Trnka M (2019) Comparison of methods for assessment of fire danger in the Czech Republic. Univ Agric Silvic Mendelianae Brun 67: 1285-1295

Konovalov IB, Beekmann M, Kuznetsova IN, Yurova A, Zvyagintsev AM (2011) Atmospheric impacts of the 2010 Russian wildfires: integrating modelling and measurements of an extreme air pollution episode in the Moscow region. Atmos Chem Phys 11:10031-10056

Krawchuk MA, Moritz MA, Parisien MA, Van Dorn J, Hayhoe K (2009) Global pyrogeography: the current and future distribution of wildfire. PLOS ONE 4:e5102

Kula E, Jankovská Z (2013) Forest fires and their causes in the Czech Republic (1992-2004). J Sci 59:41-53

Kurz WA, Dymond CC, Stinson G, Rampley GH and others (2008) Mountain pine beetle and forest carbon feedback to climate change. Nature 452:987-990

* Lampin-Maillet C, Jappiot M, Long M, Bouillon C, Morge D, Ferrier JP (2010a) Mapping wildland-urban interfaces at large scales integrating housing density and vegetation aggregation for fire prevention in the south of France. J Environ Manage 91:732-741

Lampin-Maillet C, Mantzavelas A, Galiana L, Jappiot M and others (2010b) Wildland urban interfaces. Fire behaviour and vulnerability: characterization, mapping and assessment. In: Sande SJ, Rego F, Fernandes P, Rigolot E (eds) Towards integrated fire management-outcomes of the European Project Fire Paradox. EFI Research Report No. 23. European Forest Institute, Joensuu, p 71-92

* Littell JS, Peterson DL, Riley KL, Liu YQ, Luce CH (2016) A review of the relationships between drought and forest fire in the United States. Glob Change Biol 22:2353-2369

Liu JC, Wilson A, Mickley LJ, Dominici F and others (2017) Wildfire-specific fine particulate matter and risk of hospital admissions in urban and rural counties. Epidemiology 28:77-85 
Martínez J, Vega-García C, Chuvieco E (2009) Humancaused wildfire risk rating for prevention planning in Spain. J Environ Manage 90:1241-1252

McArthur AG (1967) Fire behaviour in eucalypt forests. Forestry and Timber Bureau, Canberra

Ministerstvo zemědělství (2018) Zpráva o stavu lesa a lesního hospodářství České republiky v roce 2017 (=Report on the state of forest and forest economy in the Czech Republic in 2017). Ministerstvo zemědělství (Ministry of Agriculture), Prague

Ministerstvo zemědělství (2019) Zpráva o stavu lesa a lesního hospodářství České republiky v roce 2018 (=Report on the state of forest and forest economy in the Czech Republic in 2018). Ministerstvo zemědělství (Ministry of Agriculture), Prague

Modugno S, Balzter H, Cole B, Borrelli P (2016) Mapping regional patterns of large forest fires in wildland-urban interface areas in Europe. J Environ Manage 172: $112-126$

Možný M, Trnka M, Brázdil R (2020) Climate change drives changes of the vegetation fires in the Czech Republic. Theor Appl Climatol (in press), https://doi.org/10.1007/ s00704-020-03443-6

Naeher LP, Brauer M, Lipsett M, Zelikoff JT, Simpson CD, Koenig JQ (2007) Woodsmoke health effects: a review. Inhal Toxicol 19:67-106

Niklasson M, Zin E, Zielonka T, Feijen M and others (2010) A 350-year tree-ring fire record from Białowieża Primeval Forest, Poland: implications for Central European lowland fire history. J Ecol 98:1319-1329

Noble IR, Gill AM, Bary GAV (1980) McArthur's fire-danger meters expressed as equations. Aust J Ecol 5:201-203

Omi PN (2005) Forest fires: a reference handbook. ABCCLIO, Santa Barbara, CA

*Padilla M, Vega-García C (2011) On the comparative importance of fire danger rating indices and their integration with spatial and temporal variables for predicting daily human-caused fire occurrences in Spain. Int J Wildland Fire 20:46-58

Pausas JG, Ribeiro E (2013) The global fire-productivity relationship. Glob Ecol Biogeogr 22:728-736

* Pellegrini AFA, Ahlström A, Hobbie SE, Reich PB and others (2018) Fire frequency drives decadal changes in soil carbon and nitrogen and ecosystem productivity. Nature 553:194-198

Price O, Bradstock R (2014) Countervailing effects of urbanization and vegetation extent on fire frequency on the wildland-urban interface: disentangling fuel and ignition effects. Landsc Urban Plan 130:81-88

Pyšek P, Kučera T, Jarošík V (2002) Plant species richness of nature reserves: the interplay of area, climate and habitat in a central European landscape. Glob Ecol Biogeogr 11:279-289

Radeloff VC, Helmers DP, Kramer HA, Mockrin MH and others (2018) Rapid growth of the US wildland-urban interface raises wildfire risk. Proc Natl Acad Sci USA 115:3314-3319

Reid CE, Brauer M, Johnston FH, Jerrett M, Balmes JR, Elliott CT (2016) Critical review of health impacts of wildfire smoke exposure. Environ Health Perspect 124: 1334-1343

Rodriguez-Aseretto D, De Rigo D, Di Leo M, Cortés A, SanMiguel-Ayanz J (2013) A data-driven model for large wildfire behaviour prediction in Europe. Procedia Comput Sci 18:1861-1870
Rösch M (2000) Long-term human impact as registered in an upland pollen profile from the southern Black Forest, southwestern Germany. Veg Hist Archaeobot 9:205-218

San-Miguel-Ayanz J, Schulte E, Schmuck G, Camia A and others (2012) Comprehensive monitoring of wildfires in Europe: the European forest fire information system (EFFIS). In: Tiefenbacher J (ed) Approaches to managing disaster - assessing hazards, emergencies and disaster impacts. InTech, Rijeka, p 87-108

San-Miguel-Ayanz J, Durrant T, Boca R, Libertà G and others (2018) Forest fires in Europe, Middle East and North Africa 2017. JRC Tech Rep EUR 29318 EN. Publications Office of the European Union, Brussels

Kiikamäki P, Kangas K, Paasivaara A, Schroderus S (2015) Biodiversity attracts visitors to national parks. Biodivers Conserv 24:2521-2534

SOU (Statens Offentliga Utredningar) (2019) Skogsbränderna sommaren 2018. Rep 2019:7. SOU, Stockholm

KŠtěpánek P, Zahradníček P, Farda A, Skalák P, Trnka M, Meitner J, Rajdl K (2016) Projection of drought-inducing climate conditions in the Czech Republic according to Euro-CORDEX models. Clim Res 70:179-193

Stocks BJ, Lynham TJ, Lawson BD, Alexander ME, Van Wagner CE, McAlpine RS, Dubé DE (1989) The Canadian Forest Fire Danger Rating System: an overview. For Chron 65:258-265

Tatli H, Türkeş M (2014) Climatological evaluation of Haines forest fire weather index over the Mediterranean Basin. Meteorol Appl 21:545-552

* Taylor SW, Alexander ME (2006) Science, technology, and human factors in fire danger rating: the Canadian experience. Int J Wildland Fire 15:121-135

* Taylor KE, Stouffer RJ, Meehl GA (2012) An overview of CMIP5 and the experiment design. Bull Am Meteorol Soc 93:485-498

Taylor AH, Trouet V, Skinner CN, Stephens S (2016) Socioecological transitions trigger fire regime shifts and modulate fire-climate interactions in the Sierra Nevada, USA, 1600-2015 CE. Proc Natl Acad Sci USA 113: 13684-13689

* Trnka M, Brázdil R, Balek J, Semerádová D and others (2015) Drivers of soil drying in the Czech Republic between 1961 and 2012. Int J Climatol 35:2664-2675

* Trnka M, Semerádová D, Novotný I, Dumbrovský M and others (2016) Assessing the combined hazards of drought, soil erosion and local flooding on agricultural land: a Czech case study. Clim Res 70:231-249

Trnka M, Cienciala E, Štěpánek P and others (2020a) Systém indikátorů rizika výskytu přírodních požárů a metody predikce (=Wildfire indicators and methods of their predictions). Global Change Research Institute, Czech Academy of Sciences, Brno

* Trnka M, Hlavinka P, Možný M, Semerádová D and others (2020b) Czech drought monitor system for monitoring and forecasting agricultural drought and drought impacts. Int J Climatol (in press), https://doi.org/10.1002/ joc. 6557

*Vajda A, Venäläinen A, Suomi I, Junila P, Mäkelä HM (2014) Assessment of forest fire danger in a boreal forest environment: description and evaluation of the operational system applied in Finland. Meteorol Appl 21: 879-887

van Vuuren DP, Edmonds J, Kainuma M, Riahi K and others (2011) The representative concentration pathways: an overview. Clim Change 109:5-31 
Van Wagner CE (1987) Development and structure of the Canadian Forest Fire Weather Index System. For Tech Rep 35. Canadian Forestry Service, Ottawa

* Vicente-Serrano SM, Beguería S, López-Moreno JI (2010) A multiscalar drought index sensitive to global warming: the Standardized Precipitation Evapotranspiration Index. J Clim 23:1696-1718

Vítková L, Bače R, Kjučukov P, Svoboda M (2018) Deadwood management in Central European forests: key considerations for practical implementation. For Ecol

Editorial responsibility: Fulu Tao,

Beijing, PR China
Manage 429:394-405

* Wastl C, Schunk C, Leuchner M, Pezzatti GB, Menzel A (2012) Recent climate change: long-term trends in meteorological forest fire danger in the Alps. Agric Forest Meteorol 162-163:1-13

* Williams AP, Seager R, Macalady AK, Berkelhammer M and others (2015) Correlations between components of the water balance and burned area reveal new insights for predicting forest fire area in the southwest United States. Int J Wildland Fire 24:14-26

Submitted: March 1, 2020; Accepted: August 11, 2020 Proofs received from author(s): October 29, 2020 